\title{
El ordenamiento estatal del Patrimonio Histórico Español: Principios y bases de su Régimen Jurídico *
}

\author{
Juan Manuel Alegre Avila \\ Seminario de Derecho Administrativo \\ de la Universidad de Cantabria
}

SUMARIO: I. LAS PRINCIPALES MANIFESTACIONES DE LA TUTELA HISTORICO-ARTISTICA EN EL PRESENTE SIGLO. 1. Las Leyes de 1911 y 1915 y el Real Decreto Ley de 1926. 2. La Ley del Patrimonio Histórico-Artístico Nacional de 13 de mayo de 1933. A. La tutela monumental en la Ley de 1933. B. La protección de la riqueza mobiliaria. II LA LEY DEL PATRIMONIO HISTORICO ESPAÑOL DE 25 DE JUNIO DE 1985. 1. Las razones determinantes de la promulgación de una nueva legislación. 2. Estructura y contenido de la Ley del Patrimonio Histórico Español de 1985. III LOS PRINCIPIOS INSPIRADORES DE LA LEY DEL PATRIMONIO HISTORICO ESPAÑOL. 1. La nueva concepción del Patrimonio Histórico Español: el régimen estatutario de la propiedad histórica. 2. El derecho de acceso a la cultura y la Ley del Patrimonio Histórico Español. IV ESPECIAL REFERENCIA AL PATRIMONIO ARQUEOLOGICO. 1. La declaración como bienes de dominio público de todos los hallazgos arqueológicos. 2. Los descubrimientos casuales: derechos del propietario del terreno y del descubridor.

\footnotetext{
* El presente texto constituye la exposición escrita que fue proporcionada a los participantes en el Master organizado en marzo-abril de 1991 por la Facultad de Filología, Geografía e Historia de la Universidad del País Vasco, en colaboración con la Dirección de Patrimonio Histórico del Gobierno Vasco. La intervención oral de su autor tuvo lugar en dos sesiones, desarrolladas los días 15 y 16 de abril de 1991, en el edificio de la Facultad de Filología, en la ciudad de Vitoria. Asimismo, el texto fue suministrado a los intervinientes en el curso que, con el título "Régimen Jurídico de Promoción y Fomento del Patrimonio Histórico", tuvo lugar en Reinosa (Cantabria) durante los días 15 a 19 de julio de 1991, dentro de los II Cursos de Verano de la ciudad de Reinosa sobre Patrimonio Histórico, y que fue dirigido por el Catedrático de Derecho Administrativo de la Universidad de Cantabria, Dr. D. Luis MARTIN REBOLLO, y por el autor de estas páginas. He optado por no modificar la redacción inicial, salvo en lo que se refiere a una pequeña adición actualizadora en la nota bibliográfica. El trabajo, por tanto, data de abril de 1991.
} 


\section{LAS PRINCIPALES MANIFESTACIONES DE LA TUTELA HIS- TORICO-ARTISTICA EN EL PRESENTE SIGLO}

\section{Las Leyes de 1911 y 1915 y el Real Decreto Ley de 1926}

El artículo 46 de la Constitución española de 1978 emplaza a los poderes públicos en la tarea de garantizar la conservación y promover el enriquecimiento del patrimonio histórico, cultural y artístico de los pueblos de España y de los bienes que lo integran, cualquiera que sea su régimen jurídico y su titularidad, y prescribe asimismo que la ley penal sancionará los atentados contra este patrimonio.

Este precepto, incardinado sistemáticamente en el Capítulo $3 .^{\circ}$ del Título I del texto constitucional ( $\mathrm{De}$ los principios rectores de la política social y económica»), ha sido desarrollado por la vigente Ley del Patrimonio Histórico Español de 25 de junio de 1985, reglamentada de modo parcial por el Real Decreto 111/1986, de 10 de enero, ley que ha venido a derogar, despejando así la maraña normativa en que se ha desenvuelto tradicionalmente este sector, el conjunto de leyes que hasta su entrada en vigor habían disciplinado el ahora llamado Patrimonio Histórico Español, y, especialmente, la Ley republicana de 13 de mayo de 1933, sobre defensa, conservación y acrecentamiento del Patrimonio Histórico Artístico Nacional. Precisamente, la dispersión normativa imperante en nuestro ordenamiento de los bienes históricos ha constituido, según puede leerse en su Preámbulo, una de las razones que impulsaron al legislador de 1985 a aprobar una nueva ley en materia de patrimonio histórico, dispersión normativa a la cual vienen a añadirse, como causas que dejaron sentir la necesidad de esta Ley de 25 de junio de 1985, "la creciente preocupación sobre esta materia por parte de la comunidad internacional», así como las exigencias de la "nueva distribución de competencias entre el Estado y las Comunidades Autónomas» (Preámbulo, III).

La ley del Patrimonio Histórico Español de 25 de junio de 1985 (en adelante, LPHE) constituye, pues, en nuestro ordenamiento la culminación de una evolución legislativa, que, sin perjuicio de antecedentes más remotos, cuales la legislación de Partidas, hunde sus raíces en la política ilustrada de los Borbones en el XVIII, para alumbrar durante el pasado siglo una enorme variedad de disposiciones de muy diferente tenor, promulgadas al hilo de las concretas necesidades que en la defensa de la conservación de los bienes históricos y artísticos iban surgiendo, especialmente por lo que se refiere a la protección frente a la exportación, tradicional preocupación en este ámbito de los poderes públicos, no obstante su escasa virtualidad práctica, en modo alguno infrecuente. 
EL ORDENAMIENTO ESTATAL DEL PATRIMONIO HISTORICO ESPAÑOL

Es en el presente siglo, y a lo largo sobre todo de su primer tercio, cuando verán la luz las más importantes disposiciones orgánicas que, con una visión de conjunto, se han erigido en los precedentes normativos de la vigente LPHE. En esta línea, han de recordarse, en primer lugar, la Ley de 7 de julio de 1911, reglamentada por Real Decreto de 1 de marzo de 1912, sobre Excavaciones Arqueológicas, y la Ley de 4 de marzo de 1915, sobre Monumentos Arquitectónicos Artísticos.

La Ley del año 11, sobre antigüedades y régimen jurídico de las excavaciones arqueológicas, constituyó, incluso tras la promulgación de la Ley del Patrimonio Histórico Artístico Nacional de 1933, el cuerpo normativo en el que había de localizarse la regulación de los diferentes aspectos concernientes al patrimonio arqueológico. La Ley sienta como principio fundamental la exigencia de sometimiento a previa autorización administrativa de todas las exploraciones y excavaciones arqueológicas que pretendieran realizarse. Asimismo, procede a distinguir entre "ruinas" y "antigüedades", distinción que se corresponde con la diferenciación (de índole jurídico-civil) entre bienes inmuebles y bienes muebles (aquí, de carácter arqueológico), y que se traducirá en un diferente régimen atributivo de unas y de otras.

Así, de un lado, la Ley atribuía la propiedad de las ruinas descubiertas en el subsuelo o al demoler antiguos edificios al dueño del terreno en que las mismas fueran halladas. Por lo que se refiere a las antigüedades (bienes muebles), era preciso distinguir entre las descubiertas como consecuencia de la realización de excavaciones debidamente autorizadas y las halladas casualmente o por azar. En cuanto a las primeras, el Estado atribuía su propiedad a los excavadores por él autorizados, reservándose, en cambio, la de las antigüedades casualmente descubiertas, si bien en este caso tanto el descubridor casual como, en su caso, el dueño del terreno tenían derecho, en concepto de premio en metálico, al importe de la valoración (distribuido entre ambos por mitades) atribuida en tasación legal a la antigüedad descubierta. Precisamente, esta regulación de la Ley de 1911 constituyó, junto con la normativa del tesoro del artículo 351 del Código Civil, el fundamento de la resolución en el famoso caso de la Dama de Baza (Sentencia del Tribunal Supremo, Sala 1a, de 22 de marzo de 1976; Sentencia que, por cierto, no zanjó definitivamente la cuestión, pues con posterioridad el Tribunal Supremo, si bien en el orden contencioso-administrativo, hubo de intervenir aún dos veces, en 4 de marzo de 1983 y 10 de febrero de 1987), si bien fundamento improcedente, por cuanto tanto el artículo 351 del Código Civil como la Ley de 1911 habían sido derogadas, en el concreto punto debatido en el pleito en que se discutía la propiedad de la famosa escultura, por el artículo 40 de la Ley de 13 de mayo de 1933, que atribuía en todo caso (esto es, 
tanto en el supuesto de los descubrimientos casuales como en los que fueran consecuencia de excavaciones legalmente autorizadas) la propiedad de lo descubierto a su hallador. De ahí que la solución correcta en este caso, y a diferencia de la finalmente adoptada por el Tribunal Supremo, hubiera estribado en la atribución de la propiedad de la escultura al descubridor quien, sin embargo, había efectuado su hallazgo con extralimitación de los términos de la autorización, circunstancia en que se basó el Tribunal Supremo para calificar de «clandestino» el hallazgo y, en consecuencia, atribuir -siquiera fuera de modo indebido- su propiedad al dueño del terreno en que fue descubierta), descubridor que, en todo caso, había renunciado a sus derechos en favor del Estado.

Poco después de la Ley de Excavaciones de 1911, se promulga la de 1915 sobre Monumentos Arquitectónicos Artísticos, ley que inaugura la técnica de la calificación formal mediante expediente administrativo individualizado de los edificios que debían ser conservados. La Ley, empero, no debió de rendir adecuados resultados, como lo evidencia el intento de exportación (consecuencia de su previa separación) de las pinturas murales del convento de San Baudilio de Casillas, de Berlanga, en Soria, justamente porque el entramado protector de la Ley (tímido, por otra parte) se hacía depender de la previa declaración de Monumento Arquitectónico Artístico, circunstancia que no concurría en el caso debatido (tal y como puso de manifiesto la Sentencia del Tribunal Supremo de 12 de febrero de 1925, recaída en el pleito suscitado con ocasión de la exportación de las citadas pinturas).

Pero, sin duda, la norma más destacada, por su concepción y plasmación técnica, de este período, es el Real Decreto Ley de 9 de agosto de 1926, debido a la pluma del Ministro Callejo. Como ha afirmado el Profesor Parada Vazquez, se trata de una disposición de altura, superior incluso técnicamente a la venerada Ley de 13 de mayo de 1933, en la cual por vez primera en nuestra historia legislativa se aborda la regulación del ordenamiento protector de los bienes histórico-artísticos con pretensiones de generalidad, superando de este modo la visión parcial de las normas anteriores.

Trátase, en efecto, el citado Decreto Ley de una norma que contempla de modo global la regulación de los bienes que, integrantes del Tesoro Histórico-Artístico Nacional, debían ser conservados para la Nación (como se decía en su art. 1) "por razones de arte y cultura". No obstante lo cual, el Decreto Ley de 1926, en línea con la inspiración tradicional de nuestro ordenamiento en este ámbito, dedica una preferente atención a la regulación de la riqueza inmobiliaria, de la riqueza "monumental" existente en nuestro país, regulación que parte de la base de la previa 
EL ORDENAMIENTO ESTATAL DEL PATRIMONIO HISTORICO ESPAÑOL

calificación de los inmuebles que debían ser objeto de protección (inmuebles cuya vinculación con el territorio nacional se consideraba sustancial) en virtud de la técnica, ya ensayada desde 1915, de la formal declaración de Monumento Histórico Artístico, declaración a la cual venía anudado el conjunto de medidas de protección y defensa diseñadas en el Decreto Ley. Especialmente relevante es la conexión que las medidas de protección de la riqueza inmobiliaria tienden con el entonces en ciernes ordenamiento urbanístico, y que ha sido señalada como uno de los grandes logros de este norma («un puente entre lo artístico o monumental y lo urbanístico", en frase del Profesor Tomás Ramón Fernández), y que, desafortunadamente, no fue recogida en la Ley de 1933, hasta el punto de erigirse esta última en una de las razones determinantes de su sustitución, una vez puesto de manifiesto el alejamiento de las más depuradas técnicas urbanísticas de protección de los Monumentos y Conjuntos históricos-artísticos de la singulares medidas de tutela monumental arbitradas por la ley republicana. Pero sobre este concreto extremo volveremos dentro de unos momentos.

El Decreto Ley de 1926, como ha sido indicado, contempló de modo unitario la regulación del entero Tesoro Histórico-Artístico Nacional, comprendiendo en aquélla tanto el tratamiento de los bienes inmuebles como la riqueza mobiliaria. No obstante, y como también hemos señalado, la atención dispensada a los bienes muebles era considerablemente menos importante que la otorgada a la riqueza inmueble, inspirándose de modo prioritario la disciplina de la riqueza mobiliaria en el designio de evitar la salida del país de aquellos bienes cuya exportación pudiera ir en detrimento o menoscabo de la integridad del Tesoro mueble nacional. Al margen de este singular aspecto relativo a la exportación de los bienes muebles, sólo algún precepto aislado del Decreto Ley del 26 se dedicó a la regulación de los bienes muebles del Tesoro Histórico-Artístico Nacional.

\section{La Ley del Patrimonio Histórico-Artístico Nacional de 13 de mayo de 1933}

Con reiteración nos venimos refiriendo a la Ley de 13 de mayo de 1933, sobre defensa, conservación y acrecentamiento del Patrimonio Histórico Artístico Nacional, ley aprobada siendo Ministro de Instrucción Pública y Bellas Artes don Fernando de los Rios, y expresión de la sensibilidad cultural de los hombres de la II República, aunque, como ha quedado indicado, sus soluciones no alcanzaran en algunos puntos capitales, cual la protección monumental, especialmente de los inmuebles comprendidos en un recinto o Conjunto histórico-artístico, 
el rigor y la altura técnica del precedente Decreto Ley de 1926. La Ley del 33, no obstante, ha constituido durante más de medio siglo, hasta su derogación por la LPHE de 1985, el núcleo vertebrador y aglutinante del ordenamiento español de los bienes histórico-artísticos, habiendo asimismo inspirado la redacción de alguna importante norma extranjera, como la italiana Ley de 1 de junio de 1939, sobre los bienes de interés histórico y artístico.

La Ley de 1933 fue dictada en cumplimiento del artículo 45 de la Constitución republicana de 1931, antecedente del actual artículo 46 del texto de 1978, que situaba bajo la salvaguardia y protección del Estado la riqueza artística e histórica del país, sea quien fuere su dueño, así como de la Ley de 10 de diciembre de 1931, sobre enajenación de bienes artísticos, arqueológicos e históricos de más de cien años de antigüedad. Su artículo 1 definía el Patrimonio Histórico-Artístico Nacional, denominación que a partir de este momento adquirirá carta de naturaleza en nuestro Decreto, como el conjunto de bienes, muebles e inmuebles, de interés histórico, artístico, arqueológico o paleontológico de más de cien años de antigüedad, así como aquellos otros que, sin alcanzar la referida antigüedad, tuviesen un mérito o valor indiscutibles. Así, pues, el concepto de Patrimonio Histórico-Artístico resultaba integrado por la conjunción de dos notas: la posesión en los bienes, muebles e inmuebles, del interés a que se refería la Ley y que, en términos sintéticos, expresivos de la concepción que latía en todo el planteamiento de aquélla, podemos englobar en el binomio histórico-artístico; y, en segundo lugar, la antigüedad no inferior a cien años, salvo que se tratara de bienes de interés o valor indiscutibles, en cuyo caso, aun sin alcanzar la citada antigüedad, quedaban igualmente incluidos en el concepto de Patrimonio Histórico-Artístico y, por ende, sujetos a las prescripciones de la Ley del 33, exceptuándose en todo caso las obras de los autores vivos, que en ningún momento resultaban sometidas al régimen dispuesto en la Ley de 13 de mayo de 1933. Excepción esta última que, sin duda pretendía ampararse en la finalidad de no entorpecer indebidamente el comercio de obras de arte de autores contemporáneos, esto es, vivos, dado que el régimen de protección instaurado por la Ley era comprensivo de un conjunto de medidas fuertemente limitativas del comercio interno y externo de los bienes históricos y artísticos.

El conjunto de bienes así definidos, integrantes del Patrimonio Histórico-Artístico Nacional, constituía el ámbito de aplicación de la Ley de 13 de mayo de 1933, cuyas prescripciones se orientaban a la consecución de los objetivos de defensa, conservación y acrecentamiento de aquél, objetivos que quedaban encomendados al centro directivo por excelencia de la Administración española de las Bellas Artes, la Dirección General de 
EL ORDENAMIENTO ESTATAL DEL PATRIMONIO HISTORICO ESPAÑOL

Bellas Artes. Por otra parte, y continuando con la orientación del Decreto Ley de 1926, la Ley de 1933 pretendía erigirse en el derecho común de todos los bienes que, por su interés histórico-artístico, constituyeran manifestaciones relevantes de la creación humana. No obstante, y por lo que se refiere a la disciplina de los vestigios del más remoto pasado, esto es, los bienes de carácter o interés arqueológico o paleontológico, la Ley de 1933 se limitó a dejar subsistentes (artículo 37) los preceptos de la Ley de Excavaciones de 1911, siempre que, naturalmente, no entraran en contradicción con lo en ella establecido, cual acontecía, justamente, con lo dispuesto en el artículo 40, que, según expresamos con anterioridad, había modificado el régimen de atribución de los hallazgos arqueológicos que fueran consecuencia de descubrimientos casuales, al atribuir su propiedad en todo caso al hallador casual de los mismos, con exclusión de toda participación en el producto de lo descubierto del propietario del terreno en que el hallazgo hubiera acaecido. Normativa que, como dijimos, era de aplicación en el supuesto de la Dama de Baza, no obstante el fallo en contrario del Tribunal Supremo en aquella ocasión.

Por otro lado, el artículo 4 de la Ley de 13 de mayo de 1933 remitió a una ley especial la regulación de la riqueza documental y bibliográfica del país, ley que no fue dictada hasta casi cuarenta años después, concretamente el 21 de junio de 1972, en que se promulgó la Ley sobre Defensa y Conservación del Tesoro Documental y Bibliográfico de la Nación, igualmente derogada por la vigente de 25 de junio de 1985.

\section{A. La tutela monumental en la Ley de 1933}

La Ley de 1933 dedicó preferente atención (y la constatación no por evidente ha de dejar de ser resaltada) a la regulación de los bienes inmuebles del Patrimonio Histórico-Artístico Nacional, sin duda porque en el fondo se partía de la identificación entre aquel patrimonio y las manifestaciones de índole monumental, en cuanto expresivas de los testimonios materiales de la civilización humana concretados en obras vinculadas de una manera más intensa y permanente al territorio nacional. Apreciación que resulta confirmada por la limitación de los bienes que resultaban comprendidos en la definición de dicho Patrimonio, aquéllos que tuvieran una antigüedad, en principio, superior a cien años. Antigüedad que, como hemos señalado, suponía la exclusión de las obras de los autores contemporáneos (y aquí el legislador estaba indudablemente pensando en las obras de carácter mueble), esto es, de autores vivos, sin duda como mecanismo para evitar el entorpecimiento del comercio de las obras de arte. En todo caso, la concepción subyacente en la Ley era 
una visión de carácter esteticista o meramente contemplativa de aquellos testimonios santificados por la pátina del tiempo, concepción que se traducía adecuadamente en la relevante consideración que al legislador ofrecían los bienes inmuebles.

La Ley de 13 de mayo de 1933, cuyo Reglamento fue aprobado por Decreto de 16 de abril de 1936, instrumentó la protección de los bienes inmuebles del Patrimonio Histórico Artístico Nacional de acuerdo con la técnica inaugurada por la Ley de 1915 y continuada en el Decreto Ley de 9 de agosto de 1926, esto es, la técnica de la calificación formal en virtud de expediente administrativo tramitado y resuelto al efecto. Tratábase de un procedimiento (para cuya incoación resultaba legitimada cualquier persona, amén de las instituciones señaladas expresamente por la Ley) enderezado a la constatación de la presencia en el inmueble de aquel interés o valor exigido en el artículo 1 de la Ley, a cuyo efecto se insertaba durante su tramitación el informe preceptivo de las Reales Academias de la Historia y de Bellas Artes de San Fernando (en el supuesto de los procedimientos ordinarios de declaración, no así en el de los declarados urgentes, en cuyo caso bastaba el de la Junta Superior del Tesoro Artístico), informe que, además, era vinculante, de suerte que si el mismo no tenía carácter positivo no podía procederse a efectuar la declaración. Producida ésta, tenía lugar la incorporación del inmueble declarado a la categoría de protección instaurada en la Ley, la de Monumento Histórico-Artístico (Conjunto Histórico-Artístico, de tratarse de una agrupación de inmuebles ex artículo 33 de la Ley), declaración que iba acompañada de la inclusión en el Catálogo de Monumentos Histórico-Artísticos. Como consecuencia de la declaración y subsiguiente inclusión en el Catálogo, se producía la inserción del bien en un régimen jurídico de carácter estatutario, caracterizado por el sometimiento del mismo al conjunto de deberes y cargas impuestos por la Ley para asegurar la conservación de los valores por razón de los cuales se produjo la declaración. Régimen jurídico fuertemente limitativo de las facultades de utilización (e incluso disposición, aunque en este caso en mucha menor medida) del inmueble por parte de su propietario, utilización que, como veremos, en buena medida quedaba sustraída al mismo, desde el momento en que los usos e intervenciones que pretendieran efectuarse habían de contar con la preceptiva autorización administrativa. Por otro lado, este exigente régimen jurídico trató de compensarse con el establecimiento en favor del titular del bien de un conjunto de beneficios fiscales ordenados al fomento y mejor cumplimiento de los deberes y cargas legales, beneficios que, de este modo, se incorporaban también como caracterizadores del régimen de los Monumentos Históricos-Artísticos.

La de Monumentos Histórico-Artísticos era, pues, la única categoría legal de protección de los bienes inmuebles prevista en la ley de 1933. 
EL ORDENAMIENTO ESTATAL DEL PATRIMONIO HISTORICO ESPAÑOL

Categoría que, como hemos señalado, cuando se refería a un conjunto de inmuebles considerados como agrupación daba lugar a la declaración de Conjunto Histórico-Artístico, al cual era de aplicación el mismo régimen de protección que el previsto para los Monumentos singularmente considerados (artículo 33 de la Ley). Esta rigidez de la Ley en cuanto a la previsión de un único instrumento formal de protección, trató de ser compensada en cierta medida en el Reglamento en virtud de la formalización de un Catálogo complementario del de Monumentos Histórico-Artísticos, en el cual habrían de incluirse aquellos inmuebles que, sin poseer el relevante valor o interés justificador de la declaración de Monumento, tuvieran, sin embargo, determinadas características dignas de protección.

Pues bien, la declaración de un inmueble como Monumento HistóricoArtístico (dígase lo mismo de los comprendidos en un Conjunto) se enderezaba a preservar la integridad de los valores inherentes al mismo, preservación que se traducía en la prohibición de destrucción y, en general, de realización de cualesquiera actividades o intervenciones que fueren precisas para asegurar la más adecuada conservación del inmueble. Por otro lado, y el presente constituye un rasgo caracterizador de la legislación protectora, el inmueble objeto de un expediente de declaración como Monumento Histórico-Artístico quedaba sujeto a las prescripciones de la Ley desde el mismo momento en que se hubiera incoado el procedimiento de declaración, sin esperar, por tanto, a la resolución del procedimiento en virtud de la cual se llevara a cabo la oportuna declaración (artículo 16 de la Ley), justamente como un mecanismo cautelar orientado a preservar la intangibilidad del inmueble en tanto se resolvía el procedimiento de declaración.

El aseguramiento de la intangibilidad de los Monumentos o preservación de los valores inherentes a los mismos, objetivo, como hemos señalado, de la declaración, remitía a la Administración de las Bellas Artes el control de cuantas obras e intervenciones pretendieran llevarse a cabo en los mismos. Control instrumentado en virtud de la técnica de la preceptiva autorización administrativa, sin cuyo otorgamiento aquellas obras e intervenciones devenían clandestinas y, en consecuencia, podían ser demolidas por cuenta de los titulares de los inmuebles, tal y como vino expresamente a afirmar el artículo 6 del Decreto de 22 de julio de 1958. Amén del sometimiento a autorización administrativa, el segundo instrumento de intervención de que disponía la Administración de las Bellas Artes era la orden individual de policía, en virtud de la cual podía ordenarse a los propietarios y titulares de derechos sobre inmuebles declarados Monumentos Históricos-Artísticos la realización de las obras de consolidación y conservación necesarias para garantizar la más adecuada preservación de los 
mismos, pudiendo en ocasiones, y con sujeción a determinados requisitos, conceder a aquéllos una ayuda con carácter de anticipo reintegrable.

La Ley de 22 de diciembre de 1955, amén de reconocer en favor de los propietarios de inmuebles declarados Monumentos Histórico-Artísticos una serie de exenciones fiscales como compensación a las cargas y deberes que recaían sobre los mismos, vino a sujetar a la preceptiva autorización administrativa, en virtud de la modificación del artículo 26 de la Ley de 1933, toda utilización o cambio de uso de los referidos Monumentos, como mecanismo tendente a asegurar la destinación de los inmuebles a fines u objetivos compatibles con sus valores y caracteres histórico-artísticos. De este modo, se reforzaban los mecanismos de control administrativo, en aras, precisamente, de la garantía del mantenimiento y conservación del valor o interés histórico-artístico de los inmuebles declarados Monumentos, mecanismos que iban acompañados de la habilitación a la Administración de la potestad de expropiar los inmuebles que pusieran en peligro la conservación de los Monumentos o impidieran su contemplación, así como, en general, la de los propios Monumentos Histórico-Artísticos cuando fueran destinados por sus propietarios a fines o servicios incompatibles con su carácter histórico-artístico.

Por otro lado, el artículo 6 del antes citado Decreto de 22 de julio de 1958 amplió considerablemente las facultades interventoras de la Dirección General de Bellas Artes, desde el momento en que vino a instaurar la previa autorización del centro directivo en relación no sólo con las obras e intervenciones que pretendieran realizarse en los edificios declarados Monumentos Histórico-Artísticos, sino también cuando se tratara de obras que hubieran de localizarse en el entorno próximo de un Monumento o que pudieran afectar a su ambiente característico. De este modo, y marginando, dado su escaso interés en este momento, la eventual extralimitación de este artículo 6 respecto del contenido de la Ley del 33 y de su Reglamento de 1936, el precepto de 1958 se erigió en fuente habilitante de verdaderas potestades de ordenación urbanística en favor de la Administración de Bellas Artes, por cuanto no sólo el Monumento singularmente considerado era objeto de las facultades de control de aquélla por razón de tutela y protección de sus valores histórico-artísticos, sino que dichas facultades se extendían al «entorno" (noción, como bien puede advertirse, sumamente indeterminada y ambigua) del Monumento. A partir de este momento, y en la medida en que se produzca la consolidación de la técnica urbanística planificadora en manos de los Ayuntamientos (no se olvide que la Ley del Suelo es de 1956), tendrá lugar un progresivo distanciamiento entre la tutela monumental confiada a la Administración de Bellas Artes y la ordenación de los recintos urbanísticos como genuina competencia de los Ayuntamientos. 
EL ORDENAMIENTO ESTATAL DEL PATRIMONIO HISTORICO ESPAÑOL

La jurisprudencia, por su parte, vino a ratificar la legalidad de la preceptiva autorización de Bellas Artes ex artículo 6 del Decreto de 1958 (así, Sentencias, entre otras, de 22 de septiembre de 1966, 4 de julio de 1970, 15 de febrero de 1978 - relativa a la villa de Salvatierra de Alava, y especialmente significativa en este contexto- y 3 de octubre de 1986), desautorizando de este modo las pretensiones que, con fundamento en el aprovechamiento urbanístico conferido por el correspondiente Plan de Urbanismo, sostenían la incompetencia de la Administración de Bellas Artes para aprobar los proyectos de obras que pretendieran realizarse en el entorno de un Monumento. Si, por otro lado, y como ya nos consta, a los Conjuntos Histórico-Artísticos era de aplicación el mismo régimen que el previsto para los Monumentos, Conjuntos que, en cuanto agrupaciones de inmuebles, afectaban en ocasiones a enteras poblaciones o, al menos, a núcleos importantes de las mismas, podrá comprenderse el alcance de las que hemos dado en llamar verdaderas facultades urbanísticas de Bellas Artes, facultades desarrolladas al margen de la técnica racionalizadora que suponía el Plan, y que se concretaban en el dictado de resoluciones singulares, emanadas en atención a las características del concreto supuesto considerado, y dictadas sin referencia a unos parámetros de ordenación preestablecidos, inexistentes dada la ausencia de auténticos instrumentos planificadores a disposición de Bellas Artes. De este modo, y afirmada, con el respaldo jurisprudencial, la indubitada competencia de Bellas Artes para ordenar, por razones de tutela monumental, los recintos urbanísticos (Conjuntos Histórico-Artísticos o zonas comprendidas en el entorno de un Monumento), se producirá la coexistencia de dos ordenamientos protectores, el urbanístico municipal y el histórico-artístico en manos de Bellas Artes, ordenamientos que se ignoraban mutuamente y cuyas determinaciones entraban en frecuente colisión, dando así origen a numerosos conflictos que, una vez judicializados, concluían casi indefectiblemente en la proclamación jurisprudencial de la prevalencia de las competencias de Bellas Artes, desplegadas en ejercicio de las privativas facultades que tenía atribuidas como propias en defensa de la integridad de los valores histórico-artísticos.

En suma, y como ha sostenido el Profesor Tomás Ramón Fernández, el punto débil de la legislación de 1933, en lo que se refiere a la ordenación de los conjuntos y agrupaciones de inmuebles, estribó en que la Administración más débil, la municipal, disponía de la técnica de protección más intensa, el plan, en tanto que la Administración más poderosa, la estatal de Bellas Artes, había de ejercitar sus competencias a través de la simple orden individual de policía. Este solapamiento de Administraciones competentes y de técnicas protectoras, constatado como una de las más graves carencias de la Ley del 33, ha tratado de ser superada en la vigente de 25 de junio de 1985, en virtud de la obligatoriedad de redactar y aprobar un Plan Especial de Protección de los 
Conjuntos Históricos, Plan cuya gestión se atribuye al correspondiente Municipio. De este modo, y sin merma de las exigencias de protección de la riqueza inmobiliaria, el legislador de 1985 ha radicado en el nivel municipal el ejercicio ordinario de las competencias atinentes a los conjuntos y agrupaciones urbanos de carácter histórico.

Pero volvamos por un momento, para concluir con el tratamiento de los bienes inmuebles, al sistema de la Ley de 1933. El aludido solapamiento o entrecruzamiento de los ordenamientos urbanístico y monumental, característico de aquella legislación, alcanzó su máxima expresión con el dictado, mediante Orden del Ministerio de Educación, de las Instrucciones de 20 de noviembre de 1964. Estas Instrucciones trataban de ordenar el desarrollo urbanístico de las poblaciones declaradas Conjuntos Histórico-Artísticos, sometiendo a previa autorización de la Dirección General de Bellas Artes los proyectos de obras que pretendieran realizarse. Pero el verdadero interés de estas Instrucciones es que vinculaban el desarrollo urbanístico de las poblaciones afectadas (determinando, por ejemplo, las características de las construcciones, la índole de los materiales empleados en aquéllas, que habían de ajustarse a los tradicionalmente utilizados, la imposibilidad de incrementar los volúmenes edificatorios) con el destino socioeconómico de las mismas, destino que se pretendía orientar fundamentalmente hacia la explotación del turismo, con prohibición de la instalación en el interior de los conjuntos de aquellas industrias que excedieran de un determinado nivel de potencia energética. Por otro lado, y en torno de las poblaciones propiamente dichas se dibujaba un anillo o cinturón verde de protección, en el cual únicamente podían ubicarse aquellos usos e instalaciones expresamente permitidos.

Monumentos y Conjuntos Histórico-Artísticos constituían, pues, como sabemos, las únicas categorías legales de protección implantadas por la Ley de 1933. Monumentos y Conjuntos que, de acuerdo con la denominación de la Ley, eran de carácter nacional. El Decreto de 22 de julio de 1958, por su parte, creó dos nuevas categorías de protección, la de Monumentos Provinciales y la de Monumentos Locales, que, a diferencia de los Monumentos y Conjuntos de la Ley de 1933, cuya declaración era efectuada mediante Decreto acordado en Consejo de Ministros, serían declarados por Orden Ministerial. El cuidado y conservación de estos Monumentos provinciales y locales quedaban encomendados a los respectivos Ayuntamientos y Diputaciones Provinciales, estribando en esta razón de índole financiera la creación de esta nueva categoría de protección, por cuanto se pretendía, tal y como expresaba la Exposición de Motivos del Decreto de 58, que las ayudas estatales se concentraran en los grandes monumentos de carácter nacional, precisamente los de la Ley de 13 de mayo de 1933. 
EL ORDENAMIENTO ESTATAL DEL PATRIMONIO HISTORICO ESPAÑOL

Amén de los ya referidos (Monumentos y Conjuntos Histórico-Artísticos, Monumentos Provinciales y Locales), diferentes disposiciones vinieron a colocar bajo la tutela pública una serie muy heterogénea de bienes inmuebles. Así, el Decreto de 22 de abril de 1949 situó bajo la protección del Estado todos los castillos de España, cualquiera que fuere su estado de ruina; el Decreto 571/1963, de 14 de marzo, se encaminó a proteger los escudos, emblemas, piedras heráldicas, rollos de justicia, cruces de término y piezas similares de interés histórico-artístico; el Decreto 449/1973, de 22 de febrero, por su parte, colocó bajo la protección del Estado las construcciones conocidas con el nombre de «hórreos" o "cabazos" existentes en las regiones de Asturias y Galicia, y, más recientemente, el Real Decreto 782/1980, de 7 de Marzo, fue dictado con el designio de proteger los instrumentos musicales de carácter histórico-artístico, los cuales se consideraban consustanciales con los edificios declarados monumentos histórico-artísticos, cuando se encontraban instalados en los mismos de forma permanente (típico supuesto de inmueble por destinación: artículo $334,4 .^{\circ}$ del Código Civil), o, por el contrario, podían ser declarados individualmente monumentos histórico-artísticos de no haber recaído la citada declaración sobre el edificio en que se hallaren instalados.

\section{B. La protección de la riqueza mobiliaria}

Examinadas, siquiera sea de modo sucinto, las principales técnicas de protección de la riqueza inmobiliaria en la Ley de 1933, conviene ahora hacer una breve referencia al tratamiento legal de los bienes muebles en el texto de 13 de mayo de 1933. Tratamiento que, de acuerdo con los principios tradicionales inspiradores de la regulación en este ámbito, giró en torno a la disciplina del comercio interior y exterior de obras de arte, dado que, como es fácilmente comprensible, es con ocasión de las transmisiones puestas de manifiesto por consecuencia de la circulación de bienes muebles histórico-artísticos como de una manera más factible puede controlarse la amplitud de la riqueza mobiliaria existente. De este modo, y dado que uno de los objetivos de la Ley era la conservación del Patrimonio Histórico-Artístico Nacional, puede entenderse el diferente tenor de la regulación del comercio interior de la que aparece dispuesta en relación con el comercio externo o exportación de obras de arte. Así, por lo que a este último se refiere, y en la medida en que la salida del país de este tipo de bienes puede traducirse en un menoscabo o detrimento de la integridad del tesoro artístico nacional, el principio general sentado en el artículo 43 de la Ley era de todo punto obligado. Sentaba, en efecto, aquel precepto que la exportación debía ir precedida del permiso de la Administración de Bellas Artes, sometiéndose su otorgamiento al devengo de la correspondiente tasa de acuerdo 
con una escala progresiva establecida al efecto. En todo caso, no se permitiría, decía dicho artículo, la exportación de un bien cuya salida pudiera causar detrimento al Patrimonio Artístico Nacional. Por lo demás, el Estado resultaba habilitado para ejercer, en todo caso, el derecho de tanteo en relación con los bienes cuya exportación fuera solicitada.

En cambio, la regulación de las transmisiones de obras de arte en el interior del país se inspiraba en una lógica diferente. En este sentido, el párrafo segundo del artículo 41 y el artículo 42 de la Ley afirmaban como principio general la libertad de transmisión por los particulares y entidades mercantiles constituidas y matriculadas para los fines del comercio de antigüedades y objetos de arte, así como por los particulares en general, de los bienes muebles definidos en el artículo 1, sin el cumplimiento de otro requisito que la mera comunicación a la Administración de las cesiones o transmisiones que pretendieran efectuarse, así como de la consignación, en el supuesto de las transmisiones de los particulares previstas en el artículo 42, en escritura pública cuando aquéllas excedieran de determinada cuantía. En todo caso, el Estado podía ejercer el derecho de tanteo en las transmisiones efectuadas por particulares y entidades mercantiles dedicadas al comercio de antigüedades y obras de arte (artículo 41,2), así como este mismo derecho en los casos de venta pública, subasta o liquidación de obras de arte antiguo (artículo 52).

Con todo, el extremo más relevante de la regulación del comercio interior de bienes muebles histórico-artísticos, extremo configurado como un verdadero régimen sustantivo junto al antes aludido de libertad de las transmisiones de los particulares, venía previsto en el artículo 41 de la Ley de 1933. Se decía allí, en efecto, que los objetos muebles definidos en el artículo 1 que sean propiedad del Estado o de los organismos regionales, provinciales o locales, o que estén en posesión de la Iglesia en cualquiera de sus establecimientos o dependencias, o que pertenezcan a personas jurídicas, no se podrán ceder por cambio, venta y donación a particulares ni a entidades mercantiles. Sí podían estas mismas entidades, entre ellas, y dando cuenta a la Administración de Bellas Artes, cambiar, vender y regalar objetos de arte, encareciéndose asimismo en el artículo 41,3 que por todos los medios se fomentara el acrecentamiento de los Museos nacionales, provinciales o municipales, simplificando trámites para la cesión y depósitos en dichos centros culturales.

Prohibición, por tanto, de que las Administraciones Públicas y la Iglesia, así como las personas jurídicas en general, transmitieran o enajenaran a particulares y entidades mercantiles sus bienes muebles de carácter histórico-artístico, con excepción, como hemos indicado, de la 
posibilidad de cesión entre las mismas. Esta limitación de la facultad de disposición hallaba una clara cobertura constitucional en el texto del artículo 45 de la Constitución republicana de 1931, pudiendo localizarse su justificación material en el deseo del legislador de evitar la dispersión de las obras de arte en manos de las instituciones y entidades a que se refería el artículo 41 de la Ley de 1933, si bien, por lo que se refiere a la Iglesia (y en este punto es a todas luces evidente que la Ley estaba pensando en la Iglesia Católica, la importancia de cuyo legado histórico-artístico no es preciso encarecer), el citado texto del artículo 41 de la Ley de 13 de mayo de 1933 ha de ubicarse en el contexto sociopolítico de la II República como elemento que coadyuva a dar cuenta del sentido inspirador del precepto.

En efecto, una vez superado, por obvias razones de carácter político, el sistema del Real Decreto de 9 de enero de 1923, que sujetó a previa autorización del Ministerio de Gracia y Justicia la válida enajenación de las obras artísticas, históricas o arqueológicas de que estuvieran en posesión las entidades religiosas, e incluso, ya en la época republicana, la Ley de 10 de diciembre de 1931, que generalizó el requisito del permiso administrativo en relación con las enajenaciones que llevaran a cabo los particulares y las entidades y personas jurídicas, así eclesiásticas como civiles, el artículo 41 de la Ley de 13 de mayo de 1933 es en muy buena medida fruto del clima "anticlerical" que caracterizó a la II República, y que se tradujo en la elaboración del polémico artículo 26 de la Constitución de 9 de diciembre de 1931, clima que halló su más radical y enconada expresión con la Ley de 2 de junio de 1933, sobre Congregaciones Religiosas, que declaró, sin perjuicio del mantenimiento de su afectación al culto católico, del dominio nacional del Estado las iglesias y demás bienes histórico-artísticos de que fueran poseedoras las instituciones eclesiásticas. Naturalmente, los postulados básicos de la Ley de Congregaciones eran frontalmente opuestos a los principios de que partía la Ley del Patrimonio Histórico-Artístico de 13 de mayo de 1933, que, aun cuando prohibiera, en los términos indicados, la enajenación de sus bienes muebles, mantenía formalmente la titularidad de las entidades eclesiásticas sobre los mismos.

Pues bien, aun cuando la Ley de Congregaciones fuera posterior a la del Patrimonio Histórico-Artístico, una vez que aquélla hubo decaído como consecuencia del cambio de circunstancias políticas, será el artículo 41 de la Ley de 13 de mayo de 1933 el que se erija en régimen jurídico sustantivo de la circulación de los bienes muebles de las instituciones eclesiásticas, precepto que ha de ser completado con lo que dispuso el artículo 21 del Concordato de 27 de agosto de 1953 entre el Estado español y la Santa Sede, y que, en relación con el sistema de la Ley de 10 de diciembre de 1931, no derogada por la de 1933, dio pie a 
que los Servicios Jurídicos del Estado (Dictamen de 23 de mayo de 1988) defendieran la nulidad de una venta de candelabros alojados en una Iglesia, venta que había sido efectuada por el cura párroco de la misma sin contar con ningún tipo de autorización, administrativa o eclesiástica. En cualquier caso, el interés del asunto estriba en que la inicial venta a un anticuario había sido seguida de una ulterior transmisión, circunstancia que, a la espera de lo que en su día puedan decir los Tribunales, complica extraordinariamente el debate acerca de la titularidad de los referidos candelabros.

Sea como fuere, lo que interesa poner de relieve es la prioritaria atención que el legislador de 1933 (cuya regulación fue acompañada de lo dispuesto en los artículos 71 a 76 del Reglamento de 16 de abril de 1936) dedicó al comercio, interior y exterior, de obras de arte, atención que se vería incrementada en virtud del dictado de diferentes disposiciones reglamentarias reguladoras de la transmisión de antigüedades y obras de arte dentro y fuera del territorio nacional. Así, en este sentido, son de citar el Decreto de 12 de junio de 1953, modificado por los Decretos de 27 de enero de 1956 y 164/1969, de 6 de febrero, sobre transmisión interior y exterior de bienes muebles histórico-artísticos (y su desarrollo por Ordenes Ministeriales de 3 de marzo y 2 de diciembre de 1969), así como el Decreto 1116/1960, de 2 de junio, sobre exportación de obras de importancia histórica o artística, en cuyo artículo 1 se consideraban objetos integrantes del Tesoro Histórico Artístico Nacional (y, en consecuencia, inexportables, a tenor de su artículo 2) todos aquellos bienes muebles respecto de los que concreta y expresamente se declarara así por Orden del entonces Ministerio de Educación Nacional. Esta última disposición constituía, pues, junto al Decreto 1641/1959, de 23 de septiembre, por el que se convalidaba la exacción correspondiente a la autorización de exportación, y la Ley 43/1960, de 21 de julio, sobre traspaso a los Tribunales de Contrabando y Defraudación de la competencia para la aplicación de sanciones en materia de exportación fraudulenta de objetos integrantes del Tesoro Artistico Nacional, el régimen jurídico sustantivo de la exportación de bienes muebles de carácter histórico-artístico.

Finalmente, y a efectos de completar la referencia al régimen del comercio interior y exterior de bienes muebles integrantes del Patrimonio Histórico-Artístico Nacional, hemos de hacer mención del artículo 81 de la Ley de Expropiación Forzosa de 16 de diciembre de 1954, desarrollado por los artículos 97 a 100 de su Reglamento de 26 de abril de 1957, en el cual, y de conformidad con la normativa hasta aquí señalaba en materia de transmisiones y exportación de antigüedades y obras de arte, se regulaban los derechos de tanteo y retracto en favor de la Administración Pública. 
EL ORDENAMIENTO ESTATAL DEL PATRIMONIO HISTORICO ESPAÑOL

La Ley de 13 de mayo de 1933, por otro lado, dedicó sus artículos 66 a 72 (83 a 85 del Reglamento de 16 de abril de 1936) a regular el Inventario del Patrimonio Histórico-Artístico Nacional, cuestión absolutamente capital en toda normativa de protección de la integridad de dicho Patrimonio, desde el momento en que el desarrollo de una adecuada política de conservación de la riqueza histórico-artística exige un cabal conocimiento de los bienes que forman parte de aquel Patrimonio, esto es, exige la elaboración de los correspondientes inventarios y catálogos en los cuales se haga relación de los bienes integrantes del Patrimonio Histórico-Artístico. Precisamente, y por paradójico que pueda resultar, la catalogación de nuestro legado histórico-artístico ha constituido tradicionalmente una de las asignaturas pendientes del Derecho español de los bienes histórico-artísticos, empeño en el cual, no obstante los meritorios esfuerzos desplegados a lo largo de todo este siglo por ilustres personalidades (y aquí la mención del nombre, entre otros muchos, de don Manuel Gómez Moreno es de todo punto obligada), los resultados no siempre han acompañado a las intenciones y buenos propósitos de la Administración. De ahí el sentido de preceptos como los arriba reseñados, que, en todo caso, hubieron de ser reiterados con posterioridad, sin duda ante el fracaso de sus prescripciones. En este sentido, ha de reseñarse el Decreto de 12 de junio de 1953, por el que se dictaron disposiciones para la formalización del Inventarios del Tesoro Artístico Nacional, en cuyo artículo 1 se ordenaba la "formalización inmediata" de aquél, expresión que sin duda reflejaba fielmente el fracaso de anteriores iniciativas orientadas a la consecución de idéntica finalidad.

\section{LA LEY DEL PATRIMONIO HISTORICO ESPAÑOL DE 25 DE JUNIO DE 1985}

\section{Las razones determinantes de la promulgación de una nueva legislación}

En el Preámbulo de la vigente Ley del Patrimonio Histórico Español, Ley 16/1985, de 25 de junio, puede leerse como justificación del dictado de la misma:

«Su necesidad (la de una nueva regulación legal del Patrimonio Histórico) fue sentida, en primer término, a causa de la dispersión normativa que, a lo largo del medio siglo transcurrido desde la entrada en vigor de la venerable Ley (la de 13 de mayo de 1933), ha producido en nuestro ordenamiento jurídico multitud de fórmulas con que quisieron afrontarse situaciones concretas, en aquel momento no previstas e inexistentes. Deriva asimismo esta obligación de la creciente preocupación sobre esta materia 
por parte de la comunidad internacional y de sus organismos representativos, la cual ha generado nuevos criterios para la protección y enriquecimiento de los bienes históricos y culturales, que se han traducido en Convenciones y Recomendaciones, que España ha suscrito y observa, pero a las que su legislación interna no se adaptaba. La revisión legal queda, por último, impuesta por una nueva distribución de competencias entre el Estado y las Comunidades Autónomas que, en relación a tales bienes, emana de la Constitución y de los Estatutos de Autonomía. La presente Ley es dictada, en consecuencia, en virtud de normas contenidas en los apartados 1 y 2 del artículo 149 de nuestra Constitución, que para el legislador y la Administración estatal suponen tanto un mandato como un título competencial».

Dispersión normativa, adecuación a la normativa internacional y distribución de competencias entre el Estado y las Comunidades Autónomas, pues, como razones que confluían en la necesidad de sustituir el corpus normativo precedente y dictar una nueva regulación más acorde con las necesidades presentes. Por un lado, ya lo hemos comprobado, si bien la Ley de 1933 ha constituido, durante más de medio siglo, el núcleo vertebrador del Derecho español del Patrimonio Histórico-Artístico, su inadecuada concepción en algunos extremos decisivos de la tutela monumental (su olvido de las técnicas urbanísticas de protección), así como la proliferación en torno de la misma de multitud de disposiciones del más variado rango y contenido (sin olvidar que la misma dejó subsistentes "cuantas disposiciones se hayan dictado para la defensa y acrecentamiento del Patrimonio Histórico-Artístico Nacional en todo lo que no se opongan a las prescripciones de esta Ley») demandaban la elaboración de un auténtico código unitario de nuestro Patrimonio Histórico, según se expresa en el Preámbulo de la Ley de 25 de Junio de 1985.

En segundo lugar, y como con toda precisión recogen las palabras del Preámbulo de la LPHE, antes transcritas, «la creciente preocupación sobre esta materia por parte de la comunidad internacional y de sus organismos representativos" ha generado "nuevos criterios para la protección y enriquecimiento de los bienes históricos y culturales, que se han traducido en Convenciones y Recomendaciones, que España ha suscrito y observa, pero a las que su legislación interna no se adoptaba». En efecto, los más relevantes organismos e instituciones internacionales (UNESCO, Consejo de Europa, Comunidad Económica Europea) han desplegado en los últimos decenios una intensa labor de concienciación y efectiva protección de los más señeros vestigios de la civilización europea y universal, promoviendo, en este sentido, y en aras de la consideración de aquellos vestigios como testimonios destacados de la creación y cultura humanas, una serie de textos legales internacionales tendentes a 
EL ORDENAMIENTO ESTATAL DEL PATRIMONIO HISTORICO ESPAÑOL

reforzar el compromiso de los diferentes Estados en la labor de conservación y acrecentamiento del patrimonio cultural, concebido como patrimonio colectivo de la humanidad. De este modo, y frente a la tradicional visión conservacionista y esteticista (museística, casi) del patrimonio monumental, ha ido decantándose cada vez más la veta dinámica de aquél, como contexto en el que ha de desplegarse el desarrollo de la personalidad humana, en cuanto referencia inexcusable de una más plena y digna calidad de vida, en sus aspectos sociales y culturales. Surgirá así, como noción que ha hecho fortuna, la denominación de "bienes culturales» para referirse al conjunto de expresiones y realizaciones en que se han plasmado la civilización humana en el devenir de la historia, noción que, en un plano dogmático-jurídico, hallará en Italia su exponente más destacado, especialmente a través de la obra de Massimo Severo Giannini, y que con toda claridad luce en el texto de la ley española de 25 de junio de 1985.

Como muestras destacadas de esta preocupación internacional por la protección y acrecentamiento del patrimonio cultural podemos significar un conjunto de Tratados y Convenciones, ratificadas por España, mediante los cuales pretende canalizarse la pléyade de esfuerzos estatales en este ámbito. Así, el Convenio para la protección de los bienes culturales en caso de conflicto armado, firmado en La Haya el 14 de mayo de 1954; los Estatutos del Centro Internacional de Estudio de los problemas técnicos de la conservación y de la restauración de los bienes culturales, adoptados en París el 7 de marzo de 1958; el Convenio europeo para la protección del Patrimonio Arqueológico, hecho en Londres el 6 de mayo de 1969; la Convención sobre las medidas que deben adoptarse para prohibir e impedir la importación, la exportación y la transferencia de propiedad ilícitas de bienes culturales, hecha en París el 17 de Noviembre de 1970, o la Convención para la protección del Patrimonio Mundial Cultural y Natural, hecha en París el 23 de noviembre de 1972. Instrumentos que en virtud de su ratificación o aceptación por España vinculan internacionalmente a nuestro país, integrándose además en nuestro ordenamiento jurídico como parte del Derecho interno español (artículo 96,1 de la Constitución y 1,5 del Código Civil).

Finalmente, y como tercera razón determinante de la promulgación de una nueva Ley en materia de Patrimonio Histórico, se señalan en el Preámbulo de la LPHE las exigencias derivadas de la distribución de competencias entre el Estado y las Comunidades Autónomas, consecuencia de la estructura políticamente descentralizada del Estado surgido de la Constitución de 1978. En este sentido, ha de indicarse que los criterios constitucionales de partición competencial sobre Patrimonio Histórico (plasmados, fundamentalmente, en los artículos 148,1,16 y 149,1,28 del 
texto constitucional), concretados en el dictado por el Estado de la Ley 16/1985, de 25 de junio, han sido examinados por el Tribunal Constitucional, de resultas de la interposición de diversos recursos de inconstitucionalidad dirigidos frente a aquélla, en su Sentencia 17/1991, de 31 de enero, típico exponente de lo que, en términos jurídico-constitucionales, se denomina una sentencia interpretativa de rechazo (de rechazo, naturalmente, de los recursos de inconstitucionalidad), y en la que, sin perjuicio de afirmar la competencia del Estado (en virtud de una serie de títulos extraídos del artículo 149,1 de la Constitución) para dictar una ley del tenor de la de 25 de junio de 1985, se lleva a cabo una interpretación de diversos preceptos de la Ley para adecuarlos, en el entendimiento del Tribunal Constitucional, al esquema constitucional de distribución de competencias.

En este sentido, y como mero apunte de la doctrina del Alto Tribunal, quizá convenga resaltar en este momento que para aquél (matizando de este modo la interpretación llevada a cabo por el legislador estatal) el grueso de las competencias ejecutivas en materia de Patrimonio Histórico ha de corresponder a las Comunidades Autónomas, entre las cuales (y frente al criterio plasmado en el artículo 9 LPHE) es de mencionar la habilitación en favor de las mismas para efectuar la declaración de Bien de Interés Cultural (denominación novedosa en Derecho español y que corresponde a la categoría legal de protección más importante prevista en la LPHE). En suma, y como criterio de carácter general, para el Tribunal Constitucional (sin perjuicio de afirmarse la competencia genérica sobre cultura que en favor del Estado proclama el artículo 149,2 de la Constitución) las competencias del Estado han de localizarse primariamente en los títulos "exportación» y «expoliación» del artículo 149,1,28 (ninguna mención se hace, en cambio, en la Sentencia de 31 de enero de 1991 al concepto «interés regional» del 148,1,16 como delimitador, a contrario, de las competencias del Estado y de las Comunidades Autónomas), si bien, en todo caso, el Alto Tribunal ratifica plenamente la validez constitucional que del concepto «expoliación» contiene el artículo 4 LPHE.

\section{Estructura y contenido de la Ley del Patrimonio Histórico Es- pañol de 1985}

Expuestas sucintamente las razones básicas que impulsaron al legislador de 1985 a dictar una nueva regulación del hoy llamado Patrimonio Histórico, interesa, antes de examinar las líneas maestras de la LPHE, describir su estructura y contenido, a fin de llevar a cabo una primera aproximación al régimen jurídico de los bienes integrantes del Patrimonio Histórico Español. En este sentido, ha de indicarse que la Ley 
EL ORDENAMIENTO ESTATAL DEL PATRIMONIO HISTORICO ESPAÑOL

16/1985, de 25 de junio, asume buena parte de las técnicas de protección ensayadas tradicionalmente en Derecho español, erigiéndose en directa recipiendiaria de las soluciones del Proyecto de Ley de 14 de septiembre de 1981.

En efecto, la LPHE, conocida como Ley Solana, responsable en cuanto titular de la cartera de Cultura de la presentación a las Cortes del correspondiente Proyecto, adopta una denominación novedosa en Derecho español, la de "Patrimonio Histórico Español», prescindiendo así del calificativo "artístico" que había lucido en la hasta ahora vigente Ley de 13 de mayo de 1933. Cambio de denominación que no obedece al mero prurito innovador, sino que es consecuencia, como decía, de la nueva concepción que intenta plasmar, una concepción que, tributaria de la doctrina italiana de los "bienes culturales», concibe a los bienes integrantes de aquel Patrimonio como «el principal testigo de la contribución histórica de los españoles a la civilización universal y de su capacidad creativa contemporánea», como "riqueza colectiva que contiene las expresiones más dignas de aprecio en la aportación histórica de los españoles a la cultura universal" (en términos del Preámbulo de la propia LPHE). Esto es, concibe el Patrimonio Histórico Español, no ya como un conjunto exquisito de creaciones artísticas, sino como el resultado de la evolución de la cultura española en su evolución histórica, evolución que ha ido desgranando una serie de testimonios materiales expresivos de la radical dimensión de historicidad del ser humano.

Pues bien, la referida concepción de la LPHE intenta plasmarse normativamente a lo largo de 78 artículos estructurados en un Título Preliminar y nueve Títulos, a los que han de añadirse 8 Disposiciones Adicionales, 8 Transitorias, una Disposición Final y una Disposición Derogatoria, amén de un Preámbulo o Exposición de Motivos condensadora de las ideas cardinales de la Ley.

En el Título Preliminar (artículos 1 a 8) se contienen las llamadas «disposiciones generales», en las cuales se definen el objeto de las competencias de la Administración del Estado y se enumeran los organismos consultivos y de asesoramiento de la Administración Pública del Patrimonio Histórico; se exponen los conceptos, verdaderamente nucleares en el entramado de la Ley, de "expoliación" y "exportación»; se señala qué ha de entenderse por organismos competentes a los efectos de ejecución de la LPHE; se fijan las básicas competencias y deberes de los Ayuntamientos en la protección del Patrimonio Histórico y, finalmente, se dibujan los deberes y facultades de los ciudadanos en la labor de preservación de la integridad de aquel Patrimonio, siendo de destacar la consagración de la llamada acción pública o popular como 
mecanismo procesal enderezado a implicar a los ciudadanos en la tarea de protección y salvaguardia del Patrimonio Histórico Español.

El Título Primero de la LPHE (artículos 9 a 13) se intitula "De la declaración de Bienes de Interés Cultural». La de Bienes de Interés Cultural es, como ya notamos con anterioridad, denominación novedosa en el Derecho español de los bienes históricos, denominación que aglutina a aquellos bienes que, integrados en el genérico Patrimonio Histórico Español, son merecedores de una «singular protección y tutela». De ahí que los bienes declarados de Interés Cultural (noción más restringida y técnicamente más precisa, como se habrá advertido, que la italiana «bienes culturales», no obstante las reminiscencias, semánticas y conceptuales, presentes en aquéllas) se inserten en la más intensa categoría de protección prevista en la LPHE, inserción que supone la aplicación de un régimen jurídico de carácter estatutario (común, por lo demás, aunque en menor medida e intensidad, a todos los bienes que forman parte del Patrimonio Histórico Español) y que se traduce en la imposición de un conjunto de deberes a los propietarios y titulares de derechos sobre estos bienes, deberes que, sin embargo, van acompañados de la previsión en favor de aquéllos de una serie de medidas (básicamente, de carácter fiscal) configuradas "como fomento al cumplimiento de los deberes, y en compensación a las cargas" impuestas por la Ley, en la rigurosa definición del artículo 69,1 LPHE. Como ya se dijo, y tras la Sentencia del Tribunal Constitucional de 31 de enero de 1991, la declaración de Bien de Interés Cultural (salvo que se haya efectuado directamente por la Ley, como ocurre en el supuesto del artículo 40 LPHE) es consecuencia de la previa instrucción y resolución de un expediente administrativo por parte de las respectivas Comunidades Autónomas, declaración que va seguida de la inscripción del bien en el Registro General de Bienes de Interés Cultural previsto en el artículo 12 LPHE.

El Título II LPHE (artículo 14 a 25) se dedica a la regulación de los bienes inmuebles del Patrimonio Histórico Español. Bienes inmuebles que podrán ser declarados Bienes de Interés Cultural (artículo 14,2) como Monumentos, Jardines, Conjuntos y Sitios Históricos, así como Zonas Arqueológicas. Pues bien, la regulación de los bienes inmuebles constituye una de las grandes novedades de la LPHE, por cuanto (y recogiendo las consecuencias derivadas de la experiencia aplicativa de la Ley de 13 de mayo de 1933, así como haciéndose eco de las más actuales exigencias de la tutela monumental), el legislador de 1985 ha imbricado la protección de la riqueza inmobiliaria de carácter histórico en el marco más amplio y adecuado de las técnicas urbanísticas de protección, especialmente en lo relativo a las agrupaciones o conjuntos de inmuebles (Conjuntos y Sitios Históricos, Zonas Arqueológicas). De este modo, la 
EL ORDENAMIENTO ESTATAL DEL PATRIMONIO HISTORICO ESPAÑOL

LPHE ha consagrado la necesidad de redactar los correspondientes Planes Especiales de Protección de los Conjuntos y Sitios Históricos, así como de las Zonas Arqueológicas, declarados Bienes de Interés Cultural. Planes Especiales que habrán de ser elaborados y aprobados de acuerdo con la normativa urbanística, si bien insertando en el trámite de elaboración de los mismos (y como exigencia inexcusable de intervención de la Administración del Patrimonio Histórico por razón de protección de los específicos valores históricos que están en la base de las oportunas declaraciones) el informe favorable de los órganos competentes para la ejecución de la LPHE (artículo 20,1). El objetivo perseguido con la implantación de esta técnica de protección de los conjuntos monumentales es clara: se trata de configurar a la Administración urbanística municipal como la principal responsable de la tutela inmobiliaria, objetivo que a su vez es tributario de la convicción de que los problemas creados por la tutela monumental han de ser enmarcados y resueltos en la más amplia visión que proporcionan el Urbanismo y la planificación urbanística como módulos de resolución de las cuestiones atinentes a la ciudad.

El Título III (artículo 26 a 34) tiene por objeto la disciplina de los bienes muebles del Patrimonio Histórico Español, cuestión tradicionalmente colocada en un segundo plano de las inquietudes y preocupaciones básicas del legislador, dada la mayor relevancia atribuida a la riqueza inmueble. El artículo 26, primero de los integran el Título III, se refiere a la confección del Inventario General de bienes muebles del Patrimonio Histórico Español, en el cual se incluirán aquellos bienes que, sin alcanzar el valor que justifica la declaración de Bien de Interés Cultural, tengan sin embargo singular relevancia. En todo caso, ha de tenerse en cuenta que, a diferencia de la categoría de Bienes de Interés Cultural, en la cual podrán integrarse tanto bienes muebles como inmuebles, la de bienes del Inventario General de artículo 26 LPHE únicamente alcanza a los muebles, sin duda porque el legislador es consciente de la necesidad de establecer una gradación en el nivel de protección de la riqueza mobiliaria, protección que, de modo paralelo, es traduce en el establecimiento de diferentes cargas y deberes sobre los propietarios y titulares de derechos recayentes sobre aquéllos, y que es consecuencia, por un lado, de la inviabilidad de configurar para los bienes muebles un único y uniforme régimen jurídico, y, por otro, y en sentido contrario, de la necesidad de disponer de los suficientes instrumentos que permitan conocer de una manera exhaustiva el conjunto de la riqueza mueble, más fácil de ser ocultada y desperdigada que la inmueble. De este modo, y a través de las dos categorías de protección previstas y reguladas en la LPHE, la de Bienes de Interés Cultural y la de bienes del Inventario General, se pretende lograr el más pleno y cabal conocimiento por 
parte de la Administración, y consecuentemente la más eficaz protección, de los bienes muebles que, a tenor de la definición del artículo 1,2 LPHE, integran el Patrimonio Histórico Español.

En cualquier caso, y como bien puede comprenderse, la consecución de este objetivo dependerá de la amplitud de medios personales y materiales de que disponga la Administración (y no olvidemos que, de acuerdo con la filosofía general inspiradora de la LPHE, concretada, entre otros extremos, en la previsión, en el plano organizativo, del Consejo del Patrimonio Histórico Español, el artículo 26,1 señala que el Inventario General será elaborado por la Administración del Estado en colaboración con las demás Administraciones competentes, aunque en este punto el no claro pronunciamiento del Tribunal Constitucional en su Sentencia de 31 de enero de 1991 no permite concluir de manera inequívoca a propósito de la competencia, estatal o autonómica, para llevar a cabo las oportunas declaraciones de inclusión en el indicado Inventario), así como el grado de cumplimiento de los deberes de los ciudadanos a la hora de confeccionar el Inventario General, deberes impuestos en el artículo 26,2 LPHE.

Por lo demás, en el Título III se regulan las diferentes vicisitudes atinentes a los bienes muebles. Así, se establece la prohibición de que los muebles declarados de Interés Cultural o incluidos en el Inventario General en posesión de instituciones eclesiásticas (y la prohibición se hace extensiva a todos sus bienes integrantes del Patrimonio Histórico Español durante los diez años siguientes a la entrada en vigor de la LPHE, según la Transitoria $5^{\mathrm{a}}$ de la Ley) puedan transmitirse por título oneroso o gratuito o cederse a particulares o entidades mercantiles, bienes que sólo podrán ser enajenados o cedidos al Estado, a entidades de Derecho Público o a otras instituciones eclesiásticas (artículo 28,1, cuyo texto recuerda enormemente al del artículo 41 de la Ley de 1933). Igualmente, y con independencia de las transmisiones que entre sí puedan efectuarse, o de los supuestos de cesión del artículo 29 o de permuta del 34, las Administraciones Públicas no podrán enajenar los bienes muebles del Patrimonio Histórico Español de que sean propietarias (artículo 28,2).

Asimismo, los artículos 30 y siguientes de la LPHE regulan la exportación de bienes muebles del Patrimonio Histórico Español, los supuestos y condiciones en que podrá autorizarse la salida temporal de bienes exportables (los contemplados en el artículo 5 LPHE, esto es, los declarados de Interés Cultural o expresamente inexportables por decisión administrativa), la importación de bienes interesantes para el $\mathrm{Pa}$ trimonio Histórico Español, el ejercicio del derecho administrativo de preferente adquisición con ocasión de las solicitudes de autorización 
de exportación y la permuta de bienes muebles del Patrimonio Histórico Español.

En el Título IV (Artículos 35 a 39; "Sobre la protección de los bienes muebles e inmuebles") se contiene un conjunto de prescripciones que apelan al que podríamos denominar "núcleo duro" del régimen jurídico del Patrimonio Histórico Español y de los bienes que lo integran. En efecto, a fin de dar cumplimiento al mandato constitucional que emplaza a los poderes públicos en la tarea de garantizar la conservación de aquel Patrimonio (artículo 46), así como de lograr la consecución de uno de los objetivos señalados en el artículo 1,1 LPHE, el Título IV de la Ley, que constituye así marco de referencia inexcusable del régimen jurídico del Patrimonio Histórico y complemento indispensable del conjunto de medidas dispuestas en los precedentes Títulos II y III, sintetiza la idea matriz de todo ordenamiento protector y tuitivo de los bienes históricos, la exigencia de preservar y salvaguardar la integridad de los valores inherentes a los bienes del Patrimonio Histórico Español, aquellos valores por razón de los cuales se dispone un específico régimen de tutela y protección. La idea viene con toda claridad expresada en el artículo 36,1 LPHE, que prescribe que «los bienes integrantes del Patrimonio Histórico Español deberán ser conservados, mantenidos y custodiados por sus propietarios o, en su caso, por los titulares de derechos reales o por los poseedores de tales bienes". Deber de conservación, mantenimiento y custodia como núcleo principal del régimen tuitivo de los bienes históricos (trasunto del peculiar régimen estatutario de la propiedad histórica), que, en el caso de los más importantes de aquéllos, los declarados de Interés Cultural y los incluidos en el Inventario General, impone que su utilización quede «subordinada a que no se pongan en peligro los valores que aconsejan su conservación", así como a la exigencia de autorización administrativa de todo cambio de uso que en relación con los mismos pretenda efectuarse (artículo 36,2 LPHE).

A partir de estas ideas elementales, pero dotadas de virtualidad configuradora del entero régimen jurídico del Patrimonio Histórico, adquieren pleno encaje sistemático las medidas de protección previstas en el Título IV de la LPHE. Así, los Planes Nacionales de Información sobre el Patrimonio Histórico Español, elaborados y aprobados por el Consejo del Patrimonio Histórico Español, uno de cuyos objetivos es precisamente asegurar la protección de los bienes integrantes del Patrimonio Histórico (Artículo 35,1); la actuación de las medidas previstas en los números 3 y 4 del artículo 36 (ejecución subsidiaria, concesión de ayudas con carácter de anticipo reintegrable, realización directa por la Administración de las obras necesarias, e, incluso, expropiación por causa de interés social) en los supuestos de incumplimiento de los deberes de 
conservación, mantenimiento y custodia a que antes nos referíamos; la orden de suspensión de derribo o de cualquier clase de obra o intervención en los Bienes de Interés Cultural (artículo 37,1), orden que puede extenderse incluso al supuesto de bienes aún no declarados de Interés Cultural (artículo 37,2); la expropiación de los bienes afectados por una declaración de Interés Cultural cuando los mismos se hallen en peligro de destrucción o deterioro, o se haga de ellos un uso incompatible con sus valores, así como la expropiación de los inmuebles que impidan o perturben la contemplación de los bienes afectados por la citada declaración (artículo 37,3).

Y, en otro orden de ideas, es de destacar el deber impuesto a los poderes públicos de procurar por todos los medios de la técnica la conservación, consolidación y mejora de los Bienes de Interés Cultural y de los incluidos en el Inventario General, a cuyo efecto se impone el sometimiento a autorización administrativa de todo tratamiento que pretenda realizarse en los mismos (artículo 39,1), en el bien entendido que las citadas conservación, consolidación y rehabilitación (ideas absolutamente cardinales en todos los textos y documentos internacionales en materia de protección del patrimonio monumental, y que en nuestro Derecho han encontrado ya traducción en el plano de las ayudas financieras: Real Decreto 2329/1983, de 28 de julio —en la actualidad, Real Decreto 1932/1991, de 20 de diciembre-; tema de la rehabilitación urbana monográficamente estudiado por Fernando López Ramón), han de sujetarse en todo caso a las condiciones establecidas en el artículo 39,2 LPHE, como igualmente las restauraciones deben realizarse en los términos a que se refiere el número 3 del artículo 39. Finalmente, y aunque su ubicación en el Título de la Ley dedicado a las medidas de protección quizá no sea el más adecuado, puesto que la justificación de esta potestad no se halla sino en la idea de incrementar los patrimonios públicos de bienes históricos, el artículo 38 LPHE habilita a las Administraciones Públicas del Patrimonio Histórico para que puedan ejercitar los derechos de tanteo y retracto con ocasión de las enajenaciones de bienes declarados de Interés Cultural o incluidos en el Inventario General del artículo 26 LPHE.

Los Títulos V, VI y VII de la LPHE se dedican a regular los denominados «Patrimonios Especiales», esto es, el Arqueológico (artículos 40 a 45), el Etnográfico (artículos 46 y 47) y el Documental y Bibliográfico, así como los Archivos, Bibliotecas y Museos (artículos 48 a 66). Esta regulación en el seno de la Ley de 25 de junio de 1985 de conjuntos de bienes dotados de caracteres singulares que los individualizan como tales conjuntos o complejos, y que tradicionalmente se han localizado en textos independientes del que de una manera general regía el Patrimonio Histórico-Artístico Nacional, esto es, la Ley de 
1933 (en efecto: los bienes arqueológicos se hallaban fundamentalmente disciplinados en la Ley de 7 de julio de 1911, sin perjuicio de lo que disponían los artículos 37 a 40 de la Ley de 1933, en tanto que el llamado Tesoro Documental y Bibliográfico hallaba cobijo en la Ley de 21 de junio de 1972), obedece a la nueva concepción que del Patrimonio Histórico tiene la Ley de 1985, concepción que hemos resaltado más arriba y que desde una perspectiva sistemática se traduce, como dice el Preámbulo de la Ley, en una nueva definición de dicho Patrimonio y en una ampliación notable de su contenido.

Por otro lado, no deja de resultar paradójico que los bienes a que se refieren los citados Títulos V, VI y VII de la Ley de 25 de junio de 1985 tengan una propia denominación que los aglutina («Patrimonio Arqueológico», «Patrimonio Etnográfico», «Patrimonio Documental y Bibliográfico"), en tanto que el núcleo caracterizador de este sector del ordenamiento jurídico, los bienes a que se refieren los Títulos II y III de la LPHE, eje central de las regulaciones tradicionales en este ámbito, sean meramente designados con las denominaciones genéricas de «bienes inmuebles" y "bienes muebles». La razón de esta aparente paradoja se halla en la propia denominación de la Ley, llamada, como sabemos, del Patrimonio Histórico Español, denominación que, según hemos señalado, pretende reflejar una nueva concepción, superadora de la tradicional visión esteticista que había inspirado la regulación española, de los bienes que han de ser protegidos y transmitidos a las generaciones futuras. Nueva concepción que supone la eliminación del término "artístico" como caracterizador de este rama del ordenamiento jurídico. De ahí que si todos los bienes que integran «la contribución histórica de los españoles a la civilización universal" y que son expresión de su "capacidad creativa contemporánea" (de donde la visión unitaria y de conjunto que recoge la LPHE), se engloban en la común denominación de "Patrimonio Histórico» y si, como hemos indicado, los singulares caracteres que concurren en determinados complejos orgánicos de bienes permiten individualizarlos en atención al «interés" o "valor» que en los mismos aparece como prioritario (el "arqueológico", el «etnográfico», el "documental y bibliográfico», expresión todos ellos del genérico valor "histórico" que caracteriza a los bienes definidos en el artículo 1,2 LPHE), resulta (de ahí la paradoja a que antes aludía) que el legislador no encontrara un término específico para designar a aquellos bienes objeto tradicional de la atención de este sector, viéndose por ello obligado a denominarlos con el inespecífico nombre de «bines inmuebles» $\mathrm{y}$ «bienes muebles».

El Título V de la LPHE se dedica, como hemos dicho, a la regulación del Patrimonio Arqueológico. Sin perjuicio de volver más adelante con un cierto detenimiento sobre este tema, podemos adelantar que la gran 
innovación de la LPHE en relación con este Patrimonio estriba en la declaración contenida en el artículo 40,1, a cuyo tenor, y de conformidad con lo dispuesto en el artículo 1 LPHE, «forman parte del Patrimonio Histórico Español los bienes muebles o inmuebles de carácter histórico, susceptibles de ser estudiados con metodología arqueológica, hayan sido o no extraídos y tanto si se encuentran en la superficie o en el subsuelo, en el mar territorial o en la plataforma continental. Forman parte asímismo de este Patrimonio los elementos geológicos y paleontológicos relacionados con la historia del hombre y sus orígenes y antecedentes".

Pues bien, esta nueva concepción del Patrimonio Arqueológico que refleja la precedente declaración, y que supone la remisión legal a los criterios adoptados por la comunidad científica arqueológica, de suerte que se opera en este ámbito una recepción de los cánones válidamente admitidos en una disciplina no jurídica («susceptibles de ser estudiados con metodología arqueológica», dice el precepto), halla su correlato en el artículo 44,1 de la Ley, según el cual «son bienes de dominio público todos los objetos y restos materiales que posean los valores que son propios del Patrimonio Histórico Español y sean descubiertos como consecuencia de excavaciones, remociones de tierra u obras de cualquier índole, o por azar». A su vez, esta declaración como bienes de dominio público (no se especifica, sin embargo, si del Estado o de las correspondientes Comunidades Autónomas, competentes para autorizar las excavaciones y prospecciones arqueológicas ex artículo 42,1 LPHE) de los hallazgos arqueológicos tendrá importantes consecuencias a la hora de determinar los derechos que, como resultado del descubrimiento, puedan recaer en favor del propietario del terreno en que aquél se produjo y, en su caso, del descubridor del hallazgo. Sobre estos temas, empero, volveremos con posterioridad.

En el Título VI se contempla el llamado «Patrimonio Etnográfico», del cual forman parte (artículo 46) «los bienes muebles e inmuebles y los conocimientos y actividades que son o han sido expresión relevante de la cultura tradicional del pueblo español en sus aspectos materiales, sociales o espirituales». No se contiene, en cambio, en el referido Título VI una disciplina específica de este Patrimonio Etnográfico, disciplina que, por el contrario, ha de localizarse en los Títulos II, III y IV de la ley, reguladores, respectivamente, de los bienes inmuebles y muebles del Patrimonio Histórico Español, así como de las medidas de protección de los mismos.

El Título VII de la Ley se halla, por su parte, dividido en dos capítulos. En el primero se define y regula el Patrimonio Documental y Bibliográfico, conteniéndose en el segundo las reglas atinentes a los Archivos, 
Bibliotecas y Museos, centros de depósito en los cuales se albergan los testimonios que forman parte del Patrimonio Documental y Bibliográfico, así como, en general, los bienes muebles del Patrimonio Histórico Español. Por lo que se refiere al Patrimonio Documental y Bibliográfico(cuya definición se halla en los artículos 49 y 50 LPHE), es de mencionar la previsión en el artículo 51 de la confección del Censo de los bienes integrantes del Patrimonio Documental y del Catálogo Colectivo de los que forman parte del Patrimonio Bibliográfico, instrumentos administrativos de conocimiento y catalogación de la riqueza documental y bibliográfica, sin perjuicio, como dice el artículo 53, de que los bienes integrantes del Patrimonio Documental y Bibliográfico que tengan singular relevancia, sean incluidos en una sección especial del Inventario General de bienes muebles del Patrimonio Histórico Español. Por lo demás, el régimen sustantivo del Patrimonio Documental y Bibliográfico, en lo referente especialmente a los actos de disposición, exportación e importación de los bienes que lo integran, ha de localizarse en las disposiciones de la Ley (artículo 5 y Títulos III y IV) reguladoras con carácter general de los mencionados actos, previéndose, finalmente, en el artículo 57 la consulta de los documentos constitutivos del Patrimonio Documental Español a que se refiere el artículo 49,2 de la Ley.

El Título VIII de la LPHE se intitula "De las medidas de fomento". Como con anterioridad hemos señalado, el de los bienes históricos, justamente en atención a la consecución de los objetivos constitucional y legalmente señalados (su protección, acrecentamiento y transmisión), se configura como un régimen jurídico extraordinariamente riguroso y exigente, un régimen que impone un conjunto muy variado e importante de limitaciones, deberes y cargas que tienden a preservar la intangibilidad de los valores por razón de los cuales se erige este peculiar régimen de protección.

Pues bien, la convicción del legislador de que la consecución de los objetivos señalados en la Ley no puede lograrse de una manera eficaz si no es incentivando a los titulares de derechos sobre bienes históricos en el más pleno cumplimiento de las obligaciones legales, ha impulsado a aquél a prever un conjunto de medidas orientadas al fomento del cumplimiento de los deberes impuestos por la Ley, medidas que al mismo tiempo pasan a integrarse como constitutivas del peculiar régimen jurídico de la propiedad histórica, circunstancia que justifica que el artículo 69,1 LPHE hable de aquellas medidas no sólo como fomento al cumplimiento de los deberes legales, sino también como "compensación" por las cargas legalmente impuestas. Esta es, así, la finalidad de los artículos 67 a 74 de la Ley (completados en los artículos 58 a 66 el Reglamento de 10 de enero de 1986), artículos 
que contemplan una variada gama de medidas de fomento, tales como el acceso preferente al crédito oficial, el llamado uno por ciento cultural, diferentes beneficios fiscales (afectantes a la Contribución Territorial Urbana, hoy Impuesto sobre Bienes Inmuebles, Impuesto Extraordinario sobre el Patrimonio de las Personas Físicas, Impuesto sobre la Renta y sobre Sociedades, Impuesto sobre el Valor Añadido, exención de las importaciones, Derechos Arancelarios), así como, y de modo muy destacado, la posibilidad contemplada en el artículo 73 de la Ley (y 65 del Reglamento de 1986), que prevé que la deuda tributaria del Impuesto sobre Sucesiones, del de Patrimonio y del de la Renta pueda realizarse mediante la entrega de bienes del Patrimonio Histórico Español, posibilidad contemplada por vez primera en una Ley francesa de 1968 (conocida como Ley Malraux, en honor del entonces Ministro de Cultura francés), y actualmente extendida a otros países europeos (Italia, Bélgica).

Finalmente, en el Título IX de la Ley se tipifican las infracciones administrativas en materia de Patrimonio Histórico y se prevén las correspondientes sanciones. Título que constituye el cierre del sistema y que se endereza a otorgar a la Administración Pública los necesarios mecanismos correctores de aquellas acciones y omisiones que pongan en peligro o que supongan un efectivo atentado de los valores propios de los bienes del Patrimonio Histórico Español, previsión que ha de ser completada con los preceptos que el Código Penal dedica a la represión de las conductas atentatorias contra el patrimonio histórico, artístico y cultural (fundamentalmente, mediante la previsión de las correspondientes agravaciones de los tipos de hurtos, robos y daños).

\section{LOS PRINCIPIOS INSPIRADORES DE LA LEY DEL PATRI- MONIO HISTORICO ESPAÑOL}

\section{La nueva concepción del Patrimonio Hitórico Español: el re- gimen estatutario de la propiedad histórica}

A lo largo de la páginas precedentes hemos ido desgranando la estructura y contenido de la LPHE de 1985, labor que nos ha permitido acercarnos al examen de los objetivos a que la misma pretende atender. Hemos comprobado como la básica finalidad de proteger y conservar los testimonios materiales en que se expresa la contribución histórica de los españoles a la civilización universal y de su capacidad creativa contemporánea, se aborda desde la implantación de un régimen jurídico tuitivo y protector de la intangibilidad de los valores que son propios del Patrimonio Histórico Español, de los bienes históricos en sentido amplio. De un régimen riguroso y exigente, fuertemente 
EL ORDENAMIENTO ESTATAL DEL PATRIMONIO HISTORICO ESPAÑOL

restrictivo de las facultades de uso y, en ocasiones, de disposición de los titulares de derechos sobre los mismos, régimen que se concreta en el establecimiento de un conjunto de limitaciones, deberes y cargas, cuyo cumplimiento, no obstante, trata de fomentarse mediante la previsión de una serie de medidas de carácter incentivador, que, además, se configuran como "compensación" a las cargas impuestas en la Ley. Pues bien, el objetivo de las líneas que siguen es tratar de articular con un cierto rigor dogmático el conjunto de normas establecidas en la LP$\mathrm{HE}$, quicio del ordenamiento protector de los bienes históricos, a cuyo efecto nada mejor que reproducir el contenido de su artículo 1:

«1. Son objeto de la presente Ley la protección, acrecentamiento y transmisión a las generaciones futuras del Patrimonio Histórico Español.

2. Integran el Patrimonio Histórico Español los inmuebles y objetos muebles de interés artístico, paleontológico, arqueológico, etnográfico, científico o técnico. También forman parte del mismo el patrimonio documental y bibliográfico, los yacimientos y zonas arqueológicas, así como los sitios naturales, jardines y parques, que tengan valor artístico, histórico o antropológico.

3. Los bienes más relevantes del Patrimonio Histórico Español deberán ser inventariados o declarados de interés cultural en los términos previstos en esta Ley".

La LPHE intenta plasmar, según antes dijimos, una nueva concepción del Patrimonio Histórico Español. Nueva concepción que pretende reflejarse en la propia denominación de la Ley, de la cual ha desaparecido el tradicional adjetivo "artístico" (que lucía, por ejemplo, en la Ley de 13 de mayo de 1933), para quedar integrado exclusivamente por el término «histórico». Este cambio de denominación, como también fue señalado, pretende superar la ya tópica visión esteticista del ordenamiento español (y europeo: recuérdense, en este sentido, la Ley francesa de 31 de diciembre de 1913, sobre Monumentos Históricos, o la italiana de 1 de junio de 1939, sobre las cosas de interés histórico y artístico), para poner de manifiesto que determinados testimonios materiales son protegidos en razón de constituir "el principal testigo de la contribución histórica de los españoles a la civilización universal y de su capacidad creativa contemporánea», de representar «una riqueza colectiva que contiene las expresiones más dignas de aprecio en la aportación histórica de los españoles a la cultura universal» (Preámbulo de la LPHE, I y IX).

En suma, se pretende dar cobijo en la nueva regulación, de acuerdo con la famosa Declaración I de la italiana Comisión Franceschini 
(Comisión sobre cuyas propuestas se llevó a cabo en Italia la renovación de este sector del ordenamiento jurídico), a la noción de «bien cultural», entendido como todo testimonio material dotado de un valor de civilización («testimonianza materiale avente valore di civiltà», en la expresiva formulación italiana), noción unitaria que pretende superar las visiones sectoriales y parciales características de esta rama del ordenamiento jurídico (esto es, la existencia de una pluralidad de textos legislativos reguladores de conjuntos orgánicos de bienes: los de carácter histórico-artístico, las llamadas "bellezas naturales», los bienes arqueológicos, los bienes ambientales de carácter urbanístico, etc.), y que en definitiva sintetiza en una noción estrictamente jurídica el tratamiento de todos aquellos bienes de los que puede predicarse el ser testimonio o expresión del devenir histórico del hombre a lo largo del tiempo. De ahí que el carácter verdaderamente definitorio de esta nueva concepción de los «bienes culturales», que intenta plasmar la LPHE, sea el de la radical dimensión de "historicidad" de que aparecen revestidos determinados testimonios materiales de la cultura y la civilización (razón que explica, por ejemplo, la desaparición del requisito de una cierta antigüedad, como ocurría en el artículo 1 de la Ley española de 1933, para considerar a un bien integrante del Patrimonio Histórico Español), dimensión de "historicidad" que, sin perjuicio de continuar apoyándose en todo caso sobre las ideas de "mérito", "valor" o "interés», remite al juicio técnico-valorativo de disciplinas científicas ajenas al mundo del Derecho. Sobre esta cuestión, en todo caso, volveremos más abajo.

Nueva concepción del Patrimonio Histórico Español que, a su vez, corre paralela con la ampliación de su extensión y contenido, hasta el punto de configurar a la LPHE como el verdadero código unitario de los bienes históricos en Derecho español. Esta omnicomprensiva definición del Patrimonio Histórico Español, que se refleja en el Preámbulo de la LPHE y concreta su artículo 1, 2, no obsta, sin embargo, a la previsión de distintas categorías o niveles de protección, trasunto de la diferente intensidad de las medidas de tutela que la Ley dispensa al conjunto de bienes integrantes del genérico Patrimonio Histórico Español. Así, en el nivel máximo de protección, se sitúa la categoría de Bienes de Interés Cultural, constituida por aquellos bienes que gozarán de "singular protección y tutela" y sobre los cuales se construye el régimen más intenso y característico de cuantos confluyen en la LPHE. Un régimen integrado por un riguroso conjunto de limitaciones y deberes positivos de actuación, que, sin embargo, tratan de ser fomentados y compensados (también en el mayor nivel de intensidad previsto en la Ley) mediante una serie de incentivos y exenciones de carácter fiscal.

Por otro lado, y éste es uno de los rasgos esenciales de la nueva concepción que luce en la LPHE, traducción del derecho de acceso a la 
cultura de los artículos 44 y 46 del texto constitucional, sobre los Bienes declarados de Interés Cultural se monta, fundamentalmente, el derecho de los ciudadanos de acceder a su goce y contemplación (básicamente, a través del derecho de visita previsto en el artículo 13,2 LPHE), en la medida en que (de acuerdo con una determinada configuración dogmática que más abajo expondremos) es inherente a estos bienes una dimensión "cultural" (rectius: dicha dimensión cultural es predicable, lato sensu, de todos los «bienes culturales», en sentido amplio, si bien aquí, por obvios condicionamientos legales, constriñamos este aspecto a los formalmente declarados Bienes de Interés Cultural), dimensión que supone su "natural» puesta a disposición de los ciudadanos (en nuestro caso, además, con el respaldo que otorga la cobertura constitucional).

En segundo lugar, y en el escalón inmediatamente inferior al de los Bienes de Interés Cultural, se sitúa como categoría de protección la de los bienes incluidos en el Inventario General del artículo 26 LPHE. Categoría que, como antes dijimos, únicamente es aplicable a los bienes muebles del Patrimonio Histórico Español y que se concreta en un régimen de protección, igualmente exigente y riguroso, pero de una menor intensidad que el previsto para los bienes declarados de Interés Cultural (e, igualmente, de acuerdo con esta menor intensidad e incidencia de las potestades administrativas, en un menor acceso a las medidas de fomento establecidas en la Ley). En todo caso, la elaboración del Inventario general se justifica, como más arriba indicamos, en la necesidad de disponer de un instrumento administrativo de conocimiento y control de la riqueza mobiliaria existente, necesidad que en el caso de los bienes muebles es más apremiante, por obvias razones, que en el supuesto de los bienes inmuebles.

Finalmente, y en orden descendente, se sitúa la más genérica categoría de protección contemplada en la LPHE, aquélla que justamente da nombre a la propia Ley y que, como dice el Preámbulo, está constituida "por todos aquellos bienes de valor histórico, artístico, científico o técnico que conforman la aportación de España a la cultura universal». Esto es, se trata del conjunto de bienes que, a tenor del artículo 1,2 LP$\mathrm{HE}$, integran el Patrimonio Histórico Español, y que no hayan sido declarados de Interés Cultural o inventariados (artículo 1,3). Ambito objetivo de aplicación de la Ley que constituye el necesario sustrato o soporte sobre el cual pueden producirse las declaraciones de Interés Cultural o las resoluciones de inclusión en el Inventario General del artículo 26 LPHE.

Pues bien, como con reiteración venimos indicando, la consecución de los objetivos de la LPHE (la protección, el acrecentamiento y la 
transmisión del Patrimonio Histórico Español) se concreta en el establecimiento (si bien, como hemos dicho, en función de la diferente intensidad que suponen las distintas categorías legales de protección) de un peculiar régimen jurídico de la propiedad histórica, régimen jurídico que supone la consagración de un conjunto de limitaciones y deberes positivos de actuación por parte de los propietarios y titulares de derechos de estos bienes, y que se enderezan al mantenimiento y preservación de los valores (el «interés» a que se refiere el artículo 1,2 LPHE) ínsitos en los mismos, así como a la más plena realización del acceso por parte de los ciudadanos a su contemplación y disfrute, objetivos todos ellos cuya consecución trata de fomentarse o incentivarse mediante la previsión de una serie de medidas que compensen a sus propietarios de las cargas que sobre los mismos pesan, a fin de hacer posible lo que en el Preámbulo de la LPHE se denomina la "valoración" del Patrimonio Histórico Español, esto es, su conservación, disfrute y acrecentamiento. En cualquier caso, tratándose de un régimen protector y tuitivo de la conservación de determinados bienes, es claro que el aspecto que de una manera más destacada sobresale es el atinente a las limitaciones y restricciones que los propietarios y titulares de derechos sobre bienes históricos han de soportar, limitaciones y restricciones que vienen así a derogar o excepcionar el común régimen de libertad de uso y disposición que luce en el texto del artículo 348 del Código Civil.

En efecto, y por ofrecer una muestra significativa, los propietarios, titulares de derechos reales y poseedores de bienes declarados de Interés Cultural están obligados a permitir y facilitar su inspección por parte de los organismos competentes, su estudio a los investigadores, previa solicitud razonada de éstos, y su visita pública al menos cuatro días al mes, en días y horas previamente señalados, obligación esta última que podrá ser dispensada total o parcialmente por la Administración cuando medie causa justificada o ser sustituida por el depósito del bien, cuando se trate de bienes muebles (artículo 13,2 LPHE).

Asimismo, de tratarse de bienes inmuebles, entran en juego las prescripciones contenidas en el Título II de la LPHE, tales como la prohibición de separar aquéllos de su entorno, la necesidad de obtener autorización administrativa para realizar cualquier obra interior o exterior que afecte directamente al inmueble o a cualquiera de sus partes integrantes o pertenencias, la imposibilidad de demoler un edificio declarado en ruina si no es mediante la correspondiente autorización administrativa, o la necesidad de obtener esta misma autorización cuando se trate de realizar, por razón de fuerza mayor, obras de existir urgencia y peligro inminente de derribo (Artículos 18, 19 y 24 de la Ley). 
Igualmente, tratándose de bienes incluidos en el Inventario General del artículo 26 LPHE, los propietarios y demás titulares de derechos sobre los mismos están sujetos al cumplimiento de los deberes establecidos en el Título III de la Ley, deberes que afectan a las distintas vicisitudes atinentes a la vida jurídica de los bienes muebles comprendidos en el Inventario, comenzando por la genérica obligación de suministrar a la Administración cuanta información sea requerida a fin de proceder a la confección del indicado Inventario.

En todo caso, y como genérico marco de referencia, en el Título IV de la Ley se establece el que más arriba denominamos régimen común de la propiedad histórica, régimen centrado en torno a las medidas de protección de los bienes muebles e inmuebles del Patrimonio Histórico Español, y que se sintetiza en el genérico deber de conservación, mantenimiento y custodia del artículo 36,1, así como, más específicamente, y por lo que se refiere a los Bienes de Interés Cultural, en la subordinación del uso de los mismos a la no puesta en peligro de los valores que aconsejan su conservación, con la consiguiente necesidad de obtener autorización administrativa para todo cambio de uso pretendido.

Este conjunto de limitaciones y restricciones que pesan sobre la propiedad histórica (y que, de una manera u otra, siempre han caracterizado este sector del ordenamiento jurídico, sea en España o fuera de la misma) han hallado distintas explicaciones de orden dogmático, explicaciones que trataban de conjugar la esencia del derecho de propiedad privada como un genérico derecho de goce y disposición, con las limitaciones que pesaban sobre los propietarios, limitaciones justificadas en razones de protección y conservación de los bienes históricos, y actualmente de aseguramiento del acceso a su goce y contemplación por parte de los ciudadanos.

Así, en un primer momento, se acudió a la doctrina de las limitaciones administrativas de la propiedad privada, doctrina que veía en el conjunto de deberes y limitaciones impuestos a los propietarios una serie de restricciones o constricciones del ordinario régimen de uso y disposición, limitaciones justificadas por razones de interés público y que en todo caso dejaban a salvo la esencia del derecho de propiedad como facultad de libre utilización y disposición de los bienes sobre los que recaía. No obstante, esta explicación, una vez que las intervenciones administrativas sobre los bienes históricos adquirieron progresivamente una mayor profundidad y extensión, no daba razón suficiente de la verdadera naturaleza de los derechos, públicos y privados, que recaían sobre esta peculiar propiedad.

Y así, poniendo el acento cada vez más en la dimensión objetiva que dimanaba de los específicos caracteres de los bienes históricos, aun 
cuando sin olvidar en modo alguno el relevante papel que en todo caso correspondía al propietario privado en la consecución de los objetivos de tutela y protección pretendidos por el ordenamiento, se dirá que el propietario privado se configuraba como un ejerciente privado de funciones públicas, o como un custodio del interés público, resaltándose de este modo, cada vez con mayor intensidad, la dimensión de "función» o "interés» público que cumplen estos bienes, por encima de la perspectiva subjetiva del titular privado de derechos. Dimensión que alcanzará una destacada versión (sobre todo en Italia) en la doctrina de los «bienes de interés público», categoría intermedia entre los bienes de titularidad pública y los bienes de titularidad privada, y que trata de poner de manifiesto la existencia de un tertium genus constituido por bienes de propiedad privada que, no obstante, ofrecen un destacado interés público, razón por la cual los poderes públicos intervienen en su disciplina de una manera progresiva e intensa, y que justifica asimismo la especial sujeción o sometimiento del propietario privado a los dictados y órdenes de la Administración.

En último término, todas estas explicaciones (que, como hemos dicho, acentúan el aspecto o dimensión "objetiva» de la relación propietaria, por encima de la estricta visión subjetiva del propietario como titular de determinadas facultades) pueden sin dificultad canalizarse a través de la llamada concepción estatutaria de la propiedad, que ve en ésta no - un conjunto monolítico de facultades uniformemente establecidas por la legislación civil, sino (en consonancia con el fenómeno de disgregación del contenido unitario de la propiedad o pluralidad de estatutos dominicales o propietarios) una serie de derechos y deberes, mutuamente condicionados, establecidos por el legislador en atención a las peculiaridades de cada categoría o género de bienes, de acuerdo con el criterio de la función social (artículo 33,2 de la Constitución) que inspira la delimitación del contenido de la propiedad privada. De este modo, sería el legislador el que, en cada momento, y de acuerdo con las concepciones socialmente imperantes, definiría el contenido de cada concreto derecho de propiedad (en nuestro caso, el de la propiedad histórica), pudiendo así establecer un conjunto de deberes y cargas a cuyo cumplimiento se subordina el lícito ejercicio de las facultades dominicales. Concepción que, por otro lado, sería congruente con el postulado constitucional del Estado Social de Derecho y su plasmación en los diferentes cometidos y tareas encomendados a los poderes públicos, entre los cuales sobresale, en nuestro caso el del artículo 46 de la Constitución, que manda a los poderes públicos garantizar la conservación y promover el enriquecimiento de los bienes que integran el Patrimonio Histórico Español. Con esta explicación, pues, adquiere una dimensión (plenamente acorde con el texto constitucional, 
EL ORDENAMIENTO ESTATAL DEL PATRIMONIO HISTORICO ESPAÑOL

por cierto) más adecuada el régimen tuitivo y protector de los bienes históricos que establece la LPHE de 1985.

Concepción estatutaria de la propiedad histórica, pues, que supone la inserción de los bienes históricos en un peculiar estatuto o régimen jurídico, en aras de lograr la consecución de los objetivos de protección, acrecentamiento y transmisión del Patrimonio Histórico Español. Pero, concepción estatutaria que, sin embargo, no constituye el último ensayo a la hora de definir el contenido de la propiedad histórica, por cuanto, en último término, sigue apelando, como elemento de terminante, a la titularidad subjetiva del bien considerado. En este sentido, por tanto, ha de hacerse una ulterior referencia a la teoría italiana de los "bienes culturales», que supone, desde un punto de vista dogmático, el más elevado intento de relativización del momento subjetivo en la relación de propiedad histórica, un intento, por lo demás, que no puede entenderse sino desde las coordenadas que presiden las líneas maestras del ordenamiento que consideramos.

En efecto, a partir de la conceptuación de los bienes culturales como testimonios materiales dotados de un valor de civilización, conceptuación que, según dijimos, se halla contenida en la Declaración I de la Comisión Franceschini, Massimo Severo Giannini abordará la tarea de construir una noción jurídicamente válida de "bien cultural», como elemento aglutinante de las diferentes regulaciones que en Italia habían abordado el tratamiento de los vestigios de la cultura humana (básicamente, de los bienes de interés histórico-artístico y de las llamadas bellezas naturales, normados en dos Leyes de 1939, y de los bienes archivísticos, a que se refería un texto de 1963). En este sentido, y asumiendo la definición de la famosa Declaración I antes mencionada (siendo de destacar que el propio Giannini formó parte de la Comisión Franceschini), considerará el autor italiano que existen determinados bienes o testimonios materiales que "naturaliter» ofrecen una dimensión cultural, en cuanto expresiones del devenir histórico del hombre a lo largo del tiempo. Bienes cuya consideración "cultural», por consiguiente, no depende de una previa declaración administrativa que haga ingresar a los mismos en un peculiar estatuto jurídico, sino bienes que poseen de una manera inmanente la referida cualidad "cultural», de suerte que el acto administrativo de declaración como bienes culturales únicamente posee un valor declarativo y no constitutivo. Por eso, la noción de "bien cultural", como noción que resume jurídicamente el trato dispensado a aquellos testimonios materiales dotados de un valor de civilización, es una noción abierta, histórica y dependiente de las valoraciones técnico-valorativas que lleven a cabo las disciplinas científicas, no jurídicas, llamadas a pronunciarse acerca del interés o valor que, desde el punto de vista de la historia, concurre en los vestigios, testimonios o expresiones materiales del pasado. 
Pero, sin duda, y desde una estricta perspectiva jurídica, el aspecto más llamativo de la teoría de los «bienes culturales», tal y como fue formulada por Giannini, estriba en la relativización del elemento subjetivo o propietario recayente sobre los bienes de que es predicable su condición de testimonios dotados de un valor de civilización. En este sentido, entiende Giannini, la titularidad pública o privada de los bienes es indiferente desde el punto de vista de su conceptuación como bienes culturales. Indiferencia que, obviamente, es más acusada en el caso de los bienes de propiedad privada, por cuanto en éstos, afirma aquél, ha de distinguirse el sustrato o soporte material sobre el cual recaen titularidades estrictamente privadas, del bien cultural en sentido estricto, concebido como bien inmaterial, esto es, la función o dimensión cultural que determinados testimonios están llamados a cumplir, y cuya titularidad corresponde, no al propietario privado, sino al Estado. Apela aquí Giannini a la distinción (constatada, por otro lado, en el siglo pasado, y desde una perspectiva no jurídica, por la lúcida intuición de Víctor Hugo), de honda raigambre en el pensamiento jurídico, entre dominio directo y dominio útil (trasunto de la distinción medieval entre "corpus mechanicum" y "corpus mysticum»), distinción que remite a la teoría de la propiedad dividida, sin bien entendida en un sentido diferente al que el pensamiento jurídico tradicional le había atribuido, por cuanto la titularidad pública del bien cultural como bien inmaterial está concebida desde la estricta garantía del acceso del público al goce y contemplación de estos bienes, esto es, desde el aseguramiento de la función cultural que estos bienes están llamados a cumplir.

En último término, la doctrina de Giannini sobre los bienes culturales, doctrina polémica y no exenta de críticas (y doctrina de la que por cierto puede hallarse un eco en la Sentencia de la Sala $1^{\text {a }}$ del Tribunal Supremo de 9 de diciembre de 1985, a propósito del caso Serrano, esto es, de los derechos morales del autor, en este supuesto el escultor Pablo Serrano, sobre su obra), trata de poner en primer plano el elemento "funcional" que determinados bienes cumplen, en nuestro caso, la vocación cultural de los bienes que forman parte del Patrimonio Histórico, cuyo disfrute y contemplación por los ciudadanos han de ser asegurados por los poderes públicos a fin de hacer posible el derecho constitucionalmente garantizado de acceso a la cultura.

\section{El derecho de acceso a la cultura y la Ley del Patrimonio His- tórico Español}

Precisamente, y en relación con lo antes señalado, es como ha de enfocarse teleológicamente el sentido de la regulación de la LPHE. Porque, 
como se dice en el Preámbulo de la misma, «todas las medidas de protección y fomento que la Ley establece sólo cobran sentido si, al final, conducen a que un número cada vez mayor de ciudadanos pueda contemplar y disfrutar las obras que son herencia de la capacidad colectiva de un pueblo. Porque en un Estado democrático estos bienes deben estar adecuadamente puestos al servicio de la colectividad en el convencimiento de que con su disfrute se facilita el acceso a la cultura, y que ésta, en definitiva, es camino seguro hacia la libertad de los pueblos». Y ello en la medida en que el Patrimonio Histórico Español "es una riqueza colectiva que contiene las expresiones más dignas de aprecio en la aportación de los españoles a la cultura universal" y cuyo valor viene proporcionado por «la estima que, como elementos de identidad cultural, merece a la sensibilidad de los ciudadanos", porque "los bienes que lo integran se han convertido en patrimoniales debido exclusivamente a la acción social que cumplen, directamente derivada del aprecio con que los mismos ciudadanos los han ido revalorizando".

Es, por tanto, en cumplimiento del mandato del artículo 44, en relación con el 46 , del texto constitucional, que consagra el derecho de los ciudadanos de acceder al disfrute de la cultura (y pocas dudas pueden albergarse acerca de la radical dimensión cultural de los testimonios que se engloban en el Patrimonio Histórico Español; no otra, en definitiva, es la finalidad de la construcción de la teoría de los «bienes culturales"), como ha de enfocarse el contenido de aquellos preceptos de la LPHE destinados a hacer posible el goce y contemplación por los ciudadanos de los bienes integrantes del Patrimonio Histórico Español. Preceptos entre los cuales destaca de una manera prioritaria el artículo 13,2 LPHE (desarrollado en la Disposición Adicional $4^{a}$ del Reglamento de 10 de enero de 1986, en que se describe su contenido), que prescribe el derecho de visita pública de los bienes declarados de Interés Cultural, al menos cuatro días al mes, en días y horas previamente señalados, en las condiciones de gratuidad reglamentariamente determinadas (gratuidad inexcusable, en todo caso, para las personas que acrediten la nacionalidad española), aun cuando también sea de mencionar el derecho que asiste a los investigadores para acceder a su estudio (derecho igualmente extensible en relación con los bienes incluidos en el Inventario General ex artículo 26,6,b) LPHE, así como respecto de los integrantes del Patrimonio Documental y Bibliográfico ex artículo 52,3 LPHE), acceso con el que igualmente trata de garantizarse el genérico derecho a la cultura del mencionado artículo 44 de la Constitución.

Derecho de visita pública que, por lo demás, constituye un verdadero derecho subjetivo de los ciudadanos, de carácter constitucional, y que puede hacerse valer, ante la negativa de los propietarios de Bienes Culturales obligados a ello, ante la jurisdicción ordinaria, sin necesidad, 
por tanto, de previa intermediación de la Administración Pública competente $e x$ artículo 8,2 LPHE.

Intermediación administrativa que, sin embargo, es inexcusable cuando (al margen del aludido derecho ciudadano de visita) pretenda hacerse efectiva, por cualquier persona, el cumplimiento de las prescripciones de la LPHE, en virtud del mecanismo procesal ideado por el citado artículo 8, 2, que, como dijimos, consagra en el ámbito del Patrimonio Histórico Español una verdadera acción pública o popular para exigir ante los órganos administrativos y los Tribunales Contencioso-Administrativos el cumplimiento de la Ley de 25 de junio de 1985 en defensa de los bienes integrantes del Patrimonio Histórico Español. Acción pública o popular que, en último término, refleja el interés de todos los ciudadanos (trasunto del artículo 46 de la Constitución) en la preservación de la integridad de aquel Patrimonio.

\section{ESPECIAL REFERENCIA AL PATRIMONIO ARQUEOLOGICO}

\section{La declaración como bienes de dominio público de todos los hallazgos arqueológicos}

Una última referencia en relación con el llamado Patrimonio Arqueológico. Más arriba señalamos que, de acuerdo con el artículo 40,1 LPHE, forman parte del mismo y, por ende, del Patrimonio Histórico Español, todos los bienes muebles e inmuebles de carácter histórico "susceptibles de ser estudiados con metodología arqueológica», bienes que, por imperativo del artículo 44,1, quedan declarados de dominio público. La LPHE, siguiendo en este punto una constante de nuestro Derecho, somete a la preceptiva autorización administrativa la realización de cualesquiera actividades tendentes al descubrimiento o puesta de manifiesto de restos y hallazgos arqueológicos, esto es, de toda excavación o prospección arqueológica (artículo 42,1), considerando dilícitas las que se lleven a cabo sin la correspondiente autorización o con incumplimiento de los términos de la autorización, así como las obras de remoción de tierra, de demolición o cualesquiera otras realizadas con posterioridad en el lugar donde se haya producido un hallazgo no comunicado inmediatamente a la Administración (artículo 42,3).

\section{Los descubrimientos casuales: derechos del propietario del terreno y del descubridor}

Los hallazgos o descubrimientos de restos arqueológicos pueden producirse en virtud de excavaciones arqueológicas, como consecuencia 
de remociones de tierra u obras de cualquier índole o por azar. Si bien desde el punto de vista de la atribución de los hallazgos arqueológicos, el modo de descubrimiento es indiferente (todos los objetos y restos materiales de carácter arqueológico son, en efecto, bienes de dominio público), no lo es en cambio desde la perspectiva de los derechos atribuidos al descubridor y, en su caso, al dueño del terreno. Pues así como en el supuesto de descubrimientos que sean consecuencia de excavaciones o prospecciones debidamente autorizadas (la misma conclusión, evidentemente, es aplicable, a fortiori, en el caso de excavaciones no autorizadas o con incumplimiento de los términos de la autorización) los descubridores no tienen derecho alguno en relación con lo descubierto (artículo 42,2 LPHE), de tratarse de hallazgos casuales (definidos en el artículo 41,2), el descubridor y el propietario del lugar en que se efectuó el descubrimiento tienen derecho, en concepto de premio en metálico (no olvidemos, en este sentido, la declaración de dominio público de todos los hallazgos arqueológicos), a la mitad del valor que en tasación legal se atribuya al objeto descubierto, premio que se distribuirá entre ellos por partes iguales, manteniéndose igual proporción de ser dos o más los descubridores o propietarios.

Este sistema de atribución de premios legales, que ofrece un lejano parentesco con el establecido en el artículo 351,3 del Código Civil y en la Ley de 7 de julio de 1911 (no así, en cambio, con el del artículo 40 de la Ley de 13 de mayo de 1933, que atribuyó el producto de lo descubierto, tanto como consecuencia de excavaciones legalmente autorizadas como en el supuesto de hallazgo casuales, al descubridor), ofrece una clara justificación en el caso del descubridor casual, no así en el supuesto del propietario, a quien el legislador (quizá como reminiscencia de viejas soluciones legales) ha atribuido un premio sin duda inmerecido, pues ninguna participación (de no ser, evidentemente,y al mismo tiempo, descubridor casual) ha tenido en el hecho de rescatar para la posteridad vestigios del pasado. En todo caso, y como ya hemos señalado, los derechos de descubridor y, en su caso, propietario del terreno, lo son en concepto de premio en metálico y no como participación en el producto de lo hallado.

\section{NOTA BIBLIOGRAFICA}

El régimen jurídico vigente del Patrimonio Histórico Español se halla en la actualidad contenido (sin perjuicio de la legislación que en el ámbito de sus competencias puedan dictar las Comunidades Autónomas, cual acontece con las leyes 7/1990, de 3 de julio, del Patrimonio Cultural Vasco, y 1/1991, de 3 de julio, del Patrimonio Histórico de Andalu- 
cía) en la Ley del Patrimonio Histórico Español, Ley 16/1985, de 25 de junio, y en su Reglamento de desarrollo parcial, aprobado por Real Decreto 111/1986, de 10 de enero. Una recopilación de la legislación en la materia puede encontrarse en el volumen Legislación sobre Patrimonio Histórico, edición preparada por Javier García Fernández, con Prólogo del mismo, Tecnos, Madrid, 1987 (prólogo, por cierto, reproducido en Revista de Derecho Político. (UNED), 27-28, 1988, con el título «Presupuestos jurídico-constitucionales de la legislación sobre Patrimonio Histórico»).

Una exposición del régimen jurídico del Patrimonio Histórico-Artístico Nacional anterior a la vigente Ley de 25 de junio de 1985, en Gloria González-Ubeda Rico, Aspectos jurídicos de la protección del Patrimonio Histórico-Artístico y Cultural, Ministerio de Cultura, Madrid 1981.

La actual Ley del Patrimonio Histórico Español de 1985 ha dado ya lugar a una serie de monografías y estudios sobre la misma. Con carácter general, pueden consultarse los siguientes: Piedad García-Escudero-Benito Pendas García, El nuevo régimen jurídico del Patrimonio Histórico Español. I El Derecho del Patrimonio Histórico: Teoría General, Ministerio de Cultura, Madrid, 1986; Martín Bassols Coma, «El Patrimonio Histórico Español: aspectos de su régimen jurídico», $R e$ vista de Administración Pública, 114, 1987, 93 ss.; José Ramón Parada Vázquez, Derecho Administrativo. III. Bienes Públicos y Urbanismo, $3^{\mathrm{a}}$ ed., Marcial Pons, Madrid, 1990, 273 ss. (hay ediciones posteriores).

Asímismo, son de citar el volumen recopilativo de José Luis Alvarez Alvarez, Estudios sobre el Patrimonio Histórico Español. Civitas, Madrid, 1989, y, especialmente, las dos mejores monografías existentes en la actualidad en el mercado, las de Concepción Barrero Rodríguez, La ordenación jurídica del Patrimonio Histórico, Prólogo de Alfonso Pérez Moreno, Civitas-Instituto García Oviedo, Universidad de Sevilla, Madrid, 1990, y María del Rosario Alonso Ibáñez, El Patrimonio Histórico. Destino público y valor cultural, Prólogo de Ramón Martín MATEO, Civitas-Universidad de Oviedo, Madrid, 1992.

Igualmente, incidiendo en diversos aspectos atinentes a la regulación de los bienes históricos, puede hacerse mención de los siguientes trabajos: Vega Estella Izquierdo, «El patrimonio histórico-artístico en la jurisprudencia», Revista de Administración Pública, 76, 1975, 133 ss.; Eduardo ROCA ROCA, El Patrimonio Artístico y Cultural, IEAL, Madrid, 1976; Tomás Ramón Fernández Rodríguez, La legislación española sobre el Patrimonio Histórico-Artístico. Balance de Situación de cara al futuro, Centro Asociado de la Universidad Nacional de Educación a Distancia en Cádiz, 1978; José Bermejo Vera-Germán 
EL ORDENAMIENTO ESTATAL DEL PATRIMONIO HISTORICO ESPAÑOL

Fernández Farreres, «Actuaciones administrativas aisladas "versus» planificación: modelo urbanístico y protección del Patrimonio Histórico-Artístico», Cuadernos Aragoneses de Economía, 1981-82, 129 ss.; Eduardo García de Enterría, "Consideraciones sobre una nueva legislación del patrimonio artístico, histórico y cultural», Revista Española de Derecho Administrativo, 39, 1983, 575 ss. Del mismo modo, tres trabajos incluidos en el volumen colectivo Estudios sobre la Constitución española. Homenaje al Profesor Eduardo García de Enterría, II, Civitas, Madrid, 1991: Jesús Prieto de Pedro, Concepto y otros aspectos del Patrimonio cultural en la Constitución; Juan Manuel Alegre Avila, El ordenamiento protector de los bienes de interés cultural: consideraciones sobre su ámbito y límites. La perversión de las técnicas jurídicas de protección; Alfonso Pérez Moreno, El postulado constitucional de la protección y conservación del patrimonio histórico-artístico.

Por lo que se refiere al Derecho italiano, baste una remisión al exclente libro de Tommaso Alibrandi y Piergiorgio Ferri, I beni culturali ed ambientali, $2^{\mathrm{a}}$ ed., Giuffre, Milano, 1985. 
